\title{
Detrital modes in sedimenticlastic sands from low-order streams in the Iberian Range, Spain: the potential for sand generation by different sedimentary rocks
}

\author{
José Arribas*, Amparo Tortosa \\ Departamento de Petrologia y Geoquimica, Facultad de Ciencias Geológicas, Universidad Complutense de Madrid, Madrid 28040, Spain
}

\begin{abstract}
The composition of modern stream sands derived from sedimentary source rocks in the Iberian Range has been analyzed in order to evaluate the contributions of the different bedrock types (mainly sandstones, limestones and dolostones). Temperate to subhumid climate and short transport conditions promote a weathering-limited denudation regime. As expected, sand composition proved to be essentially quartzolithic, with variable amounts of penecontemporaneous carbonates.

Sand compositional data were compared with the exposure areas of the different bedrocks in the drainage sub-basins considered for semi-quantitative assessment of the sand generation potential of each bedrock type. Siliciclastic formations (sandstones) appear to be by far the most significant sand producers, with Sand Generation Indices (SGIs) in the medium sand fraction ranging from 4 to 20; i.e., 4 to 20 times greater than the SGI of carbonate rocks. Composition and texture are the main factors controlling carbonate sand generation. Sparitic limestones yield higher SGIs (2.8 to 20) when source terrains are constituted exclusively by carbonate rocks. High sparite grain content in the sands is enhanced by supplies from additional sources, such as calcitized dolostones. Dolomicrite sources are strongly under-represented in the sands analyzed (very low SGI), whereas the proportion of micritic limestone grains tends to be an accurate reflection of that bedrock at the source.

Even though the results presented here refer to the first stage of sand generation with negligible transport effects, we think they may be helpful in the analysis and reconstruction of source terrains in ancient sedimenticlastic deposits.
\end{abstract}

Keywords: Sand; Provenance; Recycling; Sedimentary sources; Iberian Range; Spain

\section{Introduction}

Provenance analyses on sandstones attempt to solve one of the most complex questions relating to the origin of sands: the nature of the source area and subsequent modifications of erosion products. During the 1970s and 1980s, several models were developed

\footnotetext{
* Corresponding author.

E-mail address: arribas@geo.ucm.es (J. Arribas).
}

to infer provenance from framework composition (e.g., Basu et al., 1975; Dickinson and Suczek, 1979; Dickinson, 1985; Valloni, 1985).

Subsequent studies concerned with modern sand compositions have played a crucial role in testing and improving traditional models and interpretation schemes by providing the possibility of a direct comparison between source system settings and composition of the sandy products (Ibbeken and Schleyer, 1991; Palomares and Arribas, 1993; Montesinos and 
Arribas, 1998; Arribas et al., 2000; Le Pera et al., 2001). In fact, actualistic studies can largely isølate the effects of the many closely interrelated parameters involved in the genesis of clastic sediments, including søurce-rock composition, climate, weathering and transpørt (Jøhnssøn, 1993).

Head stream sediments represent the product generated first in a fluvial system, with søurce lithølogy the dominant influence and with little or negligible modification caused by transport processes (mechanical breakdown, hydrodynamic sorting) (e.g., Basu, 1985). In order to evaluate the potential of different bedrock types for producing sand in head streams, the concept of the Sand Generation Index (SGI) was introduce by Palomares and Arribas (1993). The SGI of a given bedrock type $A$ of a dual source $\mathrm{A}+\mathrm{B}$ is expressed in terms of the outcrop area (in percentage $)$ of $\mathrm{A}\left(\% S_{\mathrm{A}}\right)$ required to produce a sand whose modal composition represents the average between the modes of sands derived from pure $A$ and B sources (Palomares and Arribas, 1993). Values -f SGI are expressed as $100 / \% S_{\mathrm{A}}$. Thus, an equal pøtential to produce sand between A and B bedreck types means a SGI equal to 2 for both bedrocks. This made it possible to evaluate quantitatively the relative capability of bedrock types to generate sand in a crystalline source terrain (granitoid + gneiss; gneiss + slate-schist and granit॰id + slate-schist bedrøck ass $\bullet$ ciations).

However, little is kn॰wn sø far ab॰ut the pøtential of the different sedimentary rock types to produce clastic sediments. The origin of sedimenticlastic deposits is related to recycling processes, the relevance of which in the genesis of detrital material has been stressed by several authors (Blatt and Jones, 1975; Garrels, 1986). In addition, petrographic criteria have been established to detect sediment recycling (F•lk, 1974; Zuffa, 1987; Arribas et al., 1990). The first attempts at quantitative assessment of the relationship between sedimentary source settings and sand compesition were made by Mack (1981), Grantham and Velbel (1988) and Ibbeken and Schleyer (1991), among others.

The purpose of this study is to compare the composition of sedimenticlastic sands in head streams with different proportions of the specific sedimentary røcks constituting the source terrains. The study area is located in the Iberian Range (Central Spain), where

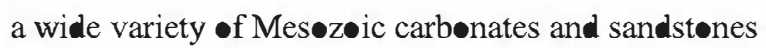
are eroded in catchment areas under temperate to subhumid climatic conditions. Several small-scale drainage sub-basins $\left(<30 \mathrm{~km}^{2}\right)$ were selected, where variables such as climate and transport effects can be considered constant or of negligible influence on sediment compesition. A quantitative analysis of the source terrains, using a gegraphical information system, permitted a detailed comparison of bedrock characteristics (lithøløgy, exposure area) with the corresponding sand composition and hence the evaluation of the relative potential for sand generation of the different sedimentary source rock types. The results may help provide a better understanding of detrital modes of sedimenticlastic deposits, especially in Tertiary basins asseciate with the Alpine chains in the Mediterranean area.

\section{Study area}

The Iberian Range is an Alpine mountain chain, abøut $400 \mathrm{~km}$ løng with a nørthwest-søutheast trend, where Mesøzic sedimentary røcks •verlying Variscan basement are widely exposed. Sedimentation during the Alpine cycle was initiated in a continental rift/ aulacogen setting and ev॰lved inte a double vergent chain due to compressive deformation from Upper Cretaceous to Upper Oligecene (Alvar et al., 1979). The drainage areas considered in this paper are located in the northwestern sector of the Iberian Range (NE of the city $\bullet$ Cuenca), covering abøut $2500 \mathrm{~km}^{2}$ (Fig. 1). In this area, the Mesøz»ic stratigraphic record consists - f a sedimentary succession up to $2600 \mathrm{~m}$ thick. Høwever, Triassic formations (abøut $1000 \mathrm{~m}$ thick) are peorly represented in the drainage basins selected, with the uppermost lutitic-evaporitic terms of the Keuper (Gernanic facies) •utcrøpping •nly locally. Jurassic units are represented by approx. $750 \mathrm{~m} \bullet$ shalløw-marine limestones with mud-supported and subordinately grain-supported textures, and doløstones. Arkoses and subarkøses prevail in the Lower Cretaceus section (300 m thick). Finally, the Upper Cretace us strata (abøut $550 \mathrm{~m}$ ) are dominated by dølømitic lithøløgies, mainly doløsparite (Vilas et al., 1982). Dedolømitization processes have been reported from this interval (Fernández Calv•, 1981). L^cally, modern travertine carbønate depøsits appear assøciated 
cover is characterized by predominantly hardwood and pine ecosystems (xerofilum, perennifolium and esclerofilum).

Human pressure on the area studied is very low, without any notable influence on sedimentary processes. Locally, deforestation has generated meadows in the lower parts of drainage basins along the river courses. Depopulation has resulted in negligible human activity (no industrial settlements and scant agriculture). Activity in the pine and hardwood forests is limited and consists of controlled pine felling.

The drainage sub-basins studied are elongated in shape, following the main Alpine structural trends of the Iberian Range (E-W, N-S and NW-SE trends). The areas occupied by these basins range from 2 to 20 $\mathrm{km}^{2}$ and all of them exhibit drainage networks at a similar stage of evolution, mainly constituted by firstand second-order streams. Drainage divides range from $1000 \mathrm{~m}$ to $1840 \mathrm{~m}$ in altitude, and mean slope values vary between $15 \%$ and $35 \%$. Water courses mainly have a seasonal regime, running during winter and spring with occasional inputs from springs. Detailed characteristics of the drainage sub-basins are shown in Fig. 2.

Channels in the highlands of the drainage areas are narrow ( 5 to $20 \mathrm{~m}$ wide) and cut deep into the bedrock (Fig. 3A). In these areas, gravel deposits prevail, exhibiting a chaotic arrangement due to local supplies from steep slopes. Channel width increases downstream (30 to $100 \mathrm{~m})$ and sandy gravel carpets and bars (longitudinal and small pointbars) develop (Fig.

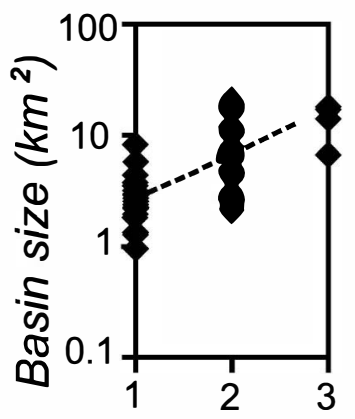

Stream order

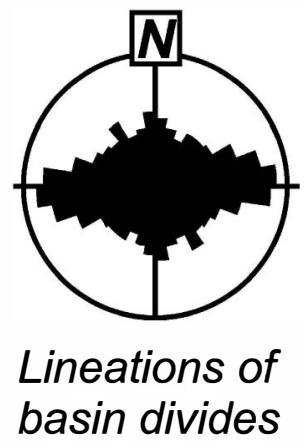

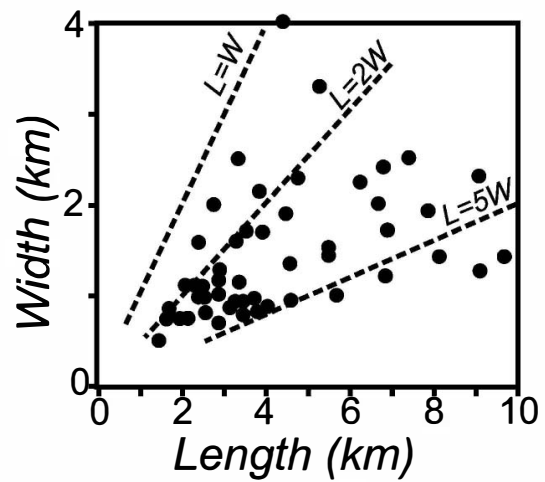

Mean slope (\%)

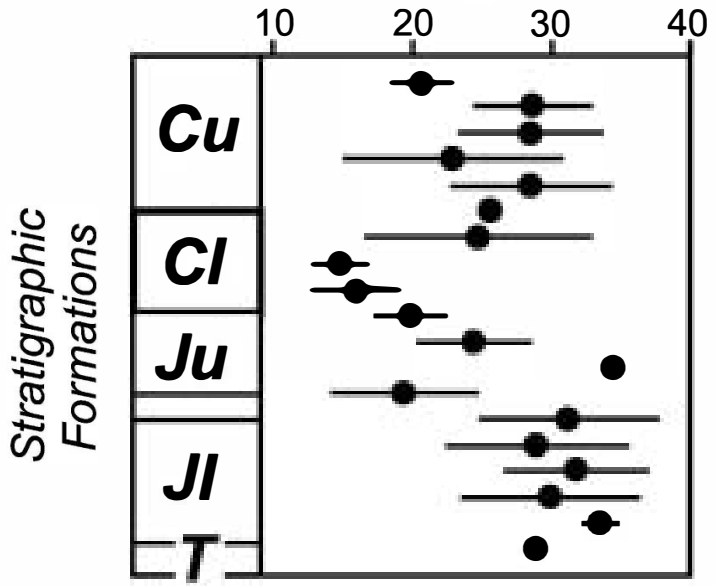

Fig. 2. Physiographic characteristics of analyzed drainage basins. T: Triassic; Jl: Lower Jurassic; Ju: Upper Jurassic; Cl: Lower Cretaceous; Cu: Upper Cretaceous. 
Table 1

Sand petrographic parameters

\begin{tabular}{|c|c|c|c|c|c|}
\hline \multirow{29}{*}{$\begin{array}{l}\text { SG } \\
\text { (single grains) }\end{array}$} & \multirow{14}{*}{$\begin{array}{l}\text { AN } \\
\text { (ancient } \\
\text { non-carbonates) }\end{array}$} & \multirow{4}{*}{ Qm } & \multirow{2}{*}{$\begin{array}{l}\text { Qs } \\
\text { Qp }\end{array}$} & \multirow{14}{*}{\multicolumn{2}{|c|}{$\begin{array}{l}\text { Monocrystalline quartz } \\
\text { Polycrystalline quartz (subgrains }>0.062 \mathrm{~mm} \text { ) } \\
\text { Quartz with evaporite inclusions } \\
\text { Quartz in rock fragment } \\
\text { K-feldspar (single grain) } \\
\text { K-feldspar in rock fragment } \\
\text { Mudrock fragment } \\
\text { Chert } \\
\text { Mica } \\
\text { Mica in rock fragment } \\
\text { Others (mainly heavy minerals and Fe-oxides) } \\
\text { Carbonate cement in sandstone } \\
\text { Ferruginous cement in sandstone } \\
\text { Phyllosilicate matrix in sandstone }\end{array}$}} \\
\hline & & & & & \\
\hline & & & Qi & & \\
\hline & & & Qr & & \\
\hline & & $\mathrm{F}$ & Ks & & \\
\hline & & $\Gamma$ & $\mathrm{Kr}$ & & \\
\hline & & I & Mf & & \\
\hline & & $\mathrm{L}$ & $\mathrm{Ch}$ & & \\
\hline & & & $\mathrm{Mc}$ & & \\
\hline & & & $\mathrm{Mr}$ & & \\
\hline & & & Ot & & \\
\hline & & & $\mathrm{Sc}$ & & \\
\hline & & & $\mathrm{Sf}$ & & \\
\hline & & & $\mathrm{Sm}$ & & \\
\hline & & & $\mathrm{Lm}$ & Micrite & Lmwp \\
\hline & & & $\mathrm{Lw}$ & Wackestone & \\
\hline & & & Lp & Packstone & \\
\hline & & CAL & $\mathrm{Lg}$ & Grainstone & Lgec \\
\hline & & & Le & Sparitic limestone & \\
\hline & & & $\mathrm{Lc}$ & Calcite single crystal & \\
\hline & (ancient & & Fo & Fossil & \\
\hline & carbonates) & & Ls & Sandy limestone & \\
\hline & & & $\mathrm{Dm}$ & Dolomicrite & \\
\hline & & & $\mathrm{De}$ & Dolosparite & Dr \\
\hline & & DOL & $\mathrm{Dc}$ & Dolomite single crystal & \\
\hline & & & Dd & Dedolomite & \\
\hline & & & Ds & Sandy dolomite & \\
\hline & $\mathrm{PC}$ & & Bio & Bioclast & \\
\hline & $\begin{array}{l}\text { (penecontempor } \\
\text { carbonates) }\end{array}$ & neous & In & Algal- and plant-induce & rbonate grain \\
\hline $\mathrm{CG}$ & $=\mathrm{SG}+$ Coeval & & $\mathrm{X}(\mathrm{SG})$ & All above classes with & al carbonate coating \\
\hline (compound grains) & carbonate coa & & En & rbonate coatır & \\
\hline & Other petrograpl & c para & & & \\
\hline & $\mathrm{Lt}=\mathrm{L}+\mathrm{AC}$ & & & & \\
\hline & $\mathrm{Q}=\mathrm{Qm}+\mathrm{Ch}$ & & & & \\
\hline
\end{tabular}

\subsection{Petrographic categories}

The petrographic database (Appendix A) is constituted by two main grain types: (1) single grains, consisting of any type of grain whose composition is related to only one source, and (2) compound grains, which have a nucleus of clastic material (single grain) with a coeval carbonate coating. The presence of compound grains is closely related to the presence of penecontemporaneous carbonate grains. Single grain types comprise six subgroups with a total of 28 petrographic classes, defined by their textures and composition (Table 1). Based on the nature of their nuclei, an equivalent number of petrographic classes of compound grains are considered (X(SG) in Table 1 and
Appendix A). Following Gazzi-Dickinson criteria, if the cross-hair fell on the nucleus that point was counted as a type of compound grain with an $\mathrm{AN}, \mathrm{AC}$ or even $\mathrm{PC}$ nucleus (X(SG) types); if it fell on the carbonate coating this point was counted as 'En' (Table 1).

\subsubsection{Ancient non-carbonates (AN)}

This subgroup mainly comprises siliciclastic monomineral (quartz, K-feldspar, micas, and heavy minerals) and polymineral grains with microcrystalline textures (i.e., lutitic grains) and coarse grained rock fragments. Monomineral grains are more abundant than either fine- or coarse-grained rock fragments. Polycrystalline quartz occur as clasts with coarse subgrains $(>0.062 \mathrm{~mm})$ or as chert grains 
(aggregates of cryptocrystalline quartz). The predominant coarse-grained fragments are sandstones with sparitic carbonate or ferruginøus cement and clay matrix. The coarse-grained rock fragments were counted as the monomineral component beneath the cross-hair (Qr, Kr, Mr, etc.). The AN subgroup is equivalent to NCE grains defined by Zuffa (1980).

\subsubsection{Calcitic components (CAL)}

These have micritic (Lmwp in Table 1) and sparitic (Lgec) textures. Micritic micrøfacies identified include micrite (Lm), wackestone (Lw) and packstone (Lp). Sparitic grains consist of coarse crystalline limestone fragments (Le) and monocrystalline calcite grains (Lc). Clasts with grainstone micrøacies (Lg) are als@ classed as 'sparitic grains', as they contain abundant sparitic cement. Echinoderm and pelecypod fragments are frequent as isølated fossils $(\mathrm{F} \bullet)$. Finally, limestone fragments with variable content of siliciclastic components (Ls) have been identified.

\subsubsection{Dolomitic components (DOL)}

These consist of dolostones grains with similar textures to the calcitic microfacies described above (Dm, De, Dc and Ds). Dw, Dp and Dg categories are n॰t recognized as sand grain microfacies. Grains with dedolømitization textures (Dd) are alsø very frequent in søme depøsits.

B॰th CAL and DOL subgroups are equivalent to AC (ancient carbonate) grains as defined by Cavazza et al. (1993), and to CE $\bullet$ Zuffa (1980).

\subsubsection{Penecontemporaneous carbonates (PC plus En)}

These encompass a wide variety of carbonate grains with micritic and sparitic textures and characterized by the presence of fine algal microstructures, as described in continental carbonates by Freytet and Verrecchia (1998). In addition, søme grains lacking these features, but with irregular borders and constituted by a 'spengy' micrite, have been included in this category (In). Their origin is associated with the erosion of travertine deposits and freshwater carb॰nate concretions (Arribas and Tortosa, 1998; Freytet and Verrecchia, 1998; Pedley, 1990). Biøclasts (Biø) are scarce, appearing løcally as fragments or as well preserved gastroped shells.

In addition, compound grains (CG in Table 1) sh॰w cœeval micritic cøatings grøwing •ver a nucleus.
These thin coatings are structureless, in some cases presenting a succession of concentric micritic bands. Counted points from these coatings have been included in the 'En' petrographic class. Nuclei •f compound grains may be included in any of the petrographic categeries described abøve.

\subsection{Quantification of source area geology}

In $\bullet$ rder to evaluate the effect of søurce area on the compesition of the sandy deposits, a søurce-area database comprising the main physiographic and lithøløic characteristics of the catchment area was constructed. The sub-basin of each sand sample was considered to comprise the portion of drainage basin that is uphill from the sample site. A geographical information system (ILWIS, version 1.4) was used to build the data base (Appendix B). Gelegical information regarding the percentages of $\bullet$ utcrøp area $\bullet$ the different cartographic units in the sub-basins was acquire from gelogic maps at 1:50,000 scale (I.T.G.E., 1983a,b, 1986, 1989a,b,c) and transformed by digitizing inte pølygen and raster map formats. Slope data were obtained from a digital elevation model generated by digitization of top graphic maps (scale 1:50,000). Tables with the outcrøp area and the related slope data of each cartographic unit are created by combining pixel values ('crossing') of

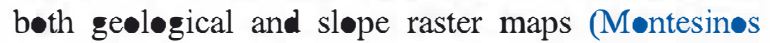
and Arribas, 1998). Often, digitized cartographic units from gelogic maps comprise more than one lithølogy. However, these cartographic data have been transformed int lith logic-type percentages by using additional information from map memoirs and unpublished complementary data (cross sections, petrographic data and detailed descriptions). This transformation has been applied to each geological sheet (scale $1: 50,000$ ) being applicable only to the sub-basins eccurring in that sheet. Table 2 illustrates an example of this transformation (sheet no. 564). The authors can provide transformations from the -ther sheets on request. In søme cases, the lithølogic information has prove to be scarce, and detailed compositional data are lacking. We thus distinguished brøad but simple lithølogic grøups: micritic limestone (Lmwp); sparitic limestone (Lgec); finecrystalline dolostones (Dm); medium- to coarse-crystalline dolostones (Dr); siliciclastics (AN) and marls 
Lithof acies of the cartographic units from sheet no. 564 (Fuertescusa), used for ransf ormation of cartographic data into lithologic parameters of sub-basins in sheet no. 564

\begin{tabular}{|c|c|c|c|c|c|c|c|c|c|c|c|}
\hline \multicolumn{12}{|c|}{ Fuertescusa (no. 564) } \\
\hline & & \multicolumn{2}{|c|}{ Cartographic units } & \multicolumn{8}{|c|}{ Lithof acies $(\%)$} \\
\hline & & & & $\overline{\mathrm{Lm}^{\mathrm{a}}}$ & $\mathrm{Lw}^{\mathrm{a}}$ & $L p^{a}$ & $\mathrm{Lg}^{\mathrm{a}}$ & $\mathbf{D m}^{\mathrm{a}}$ & $\operatorname{Dr}^{\mathrm{a}}$ & $\mathrm{AN}^{\mathrm{b}}$ & $\overline{\operatorname{Mar}^{c}}$ \\
\hline & & 12 & Fm. Calizas dolomíticas del Pantano de la Tranquera & & & & & & 100 & & \\
\hline & & 11 & Fm. Dolomías de la Ciudad Encantada & & & & 25 & & 75 & & \\
\hline & $\mathrm{Cl}$ & 9 & Facies Weald; Fm. Arenas de Utrillas & & 3 & & & & & 89 & 8 \\
\hline & & 8 & Fm. Arenas de Utrillas & & & & & & & 100 & \\
\hline & & 7 & Facies Weald & & 10 & & & & & 70 & 20 \\
\hline \multirow[t]{3}{*}{ Jurassic } & $\mathrm{Jm}$ & 6 & Fm. Carbonatada de Chelva & 50 & 50 & & & & & & \\
\hline & $\mathrm{Jl}$ & 5 & Fm. Margas y Calizas de Turmiel & & & & & & & & 100 \\
\hline & & 4 & $\begin{array}{l}\text { Fm. Margas del Cerro del Pez; Fm. Calizas } \\
\text { bioclásticas de Barahona }\end{array}$ & 50 & 50 & & & & & & \\
\hline
\end{tabular}

Jl: Lower Jurassic; Jm: Middle Jurassic; Cl: Lower Cretaceous; Cu: Upper Cretaceous.

Source of information: Complementary data of the 564 sheet, Instituto Tecnológico y Geominero de España (I.T.G.E.).

${ }^{a}$ See Table 1 for explanation.

b Siliciclastics (mainly conglomerates and sandstones).

${ }^{\mathrm{c}}$ Marls.

(Mar). Transformation of cartographic units int lithøløgic groups can be expressed as a matrix multiplication:

$\mathrm{L} x=\left|\begin{array}{cccc}\lg _{11} & \lg _{12} & \ldots & \lg _{1 n} \\ \lg _{21} & \lg _{22} & \ldots & \lg _{2 n} \\ \ldots & \ldots & \ldots & \ldots \\ \lg _{m 1} & \lg _{m 2} & \ldots & \lg _{m n}\end{array}\right| \cdot\left|\begin{array}{c}\mathrm{CU}_{1} \\ \mathrm{CU}_{2} \\ \ldots \\ \mathrm{CU}_{n}\end{array}\right|=\left|\begin{array}{c}\mathrm{LG}_{1} \\ \mathrm{LG}_{2} \\ \ldots \\ \mathrm{LG}_{m}\end{array}\right|: 1 \mathbf{0 0}$

where, $1 g_{m n}$ is the percentage of the $\boldsymbol{m}$ lithølogic group that is represented in a given $n$ cartographic unit; $\mathrm{CU}_{n}$ is the area $(\%)$ of the $n$ cartographic unit from the $x$ sub-basin; and $L_{m}$ the percentage of representation of the $m$ litholøgic group in the $x$ subbasin. The final source lithology database for the sub-basin involved in the genesis of each sample is shown in Appendix B. Travertines and other recent carbonate formations appear to be associated to stream courses and are not represented on 1:50,000 scale geløgic maps. Thus, quantification of recent

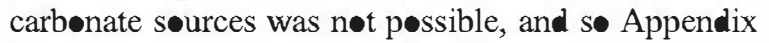
$\mathrm{B}$ refers only to ancient bedrecks.

\section{Stream sand composition}

Mødal sand compesition in fine, medium and cœarse grain-size intervals varies considerably, from nearly pure siliciclastic sand to nearly pure carbnate-røck-fragment sand (Fig. 4). Penecontemporaneous carbonates (PC plus En) do not generally exceed $25 \%$ of total grain population. These variations in sand composition reflect a wide variety of sedimentary sources in the different sub-basins and the productivity of those sub-basins as coeval carbønate sources. Occasionally, penecontemporaneous carbonate content exceeds $\mathbf{9 0 \%}$ of the bulk sediment, causing considerable dilution of nøn-carbonate (AN) and carbonate-rock-fragment grains (AC) supplied by the source rocks. The concentration of penecontemporaneous carbonates in fine, medium and coarse grain size fractions is shown in Fig. 4. 


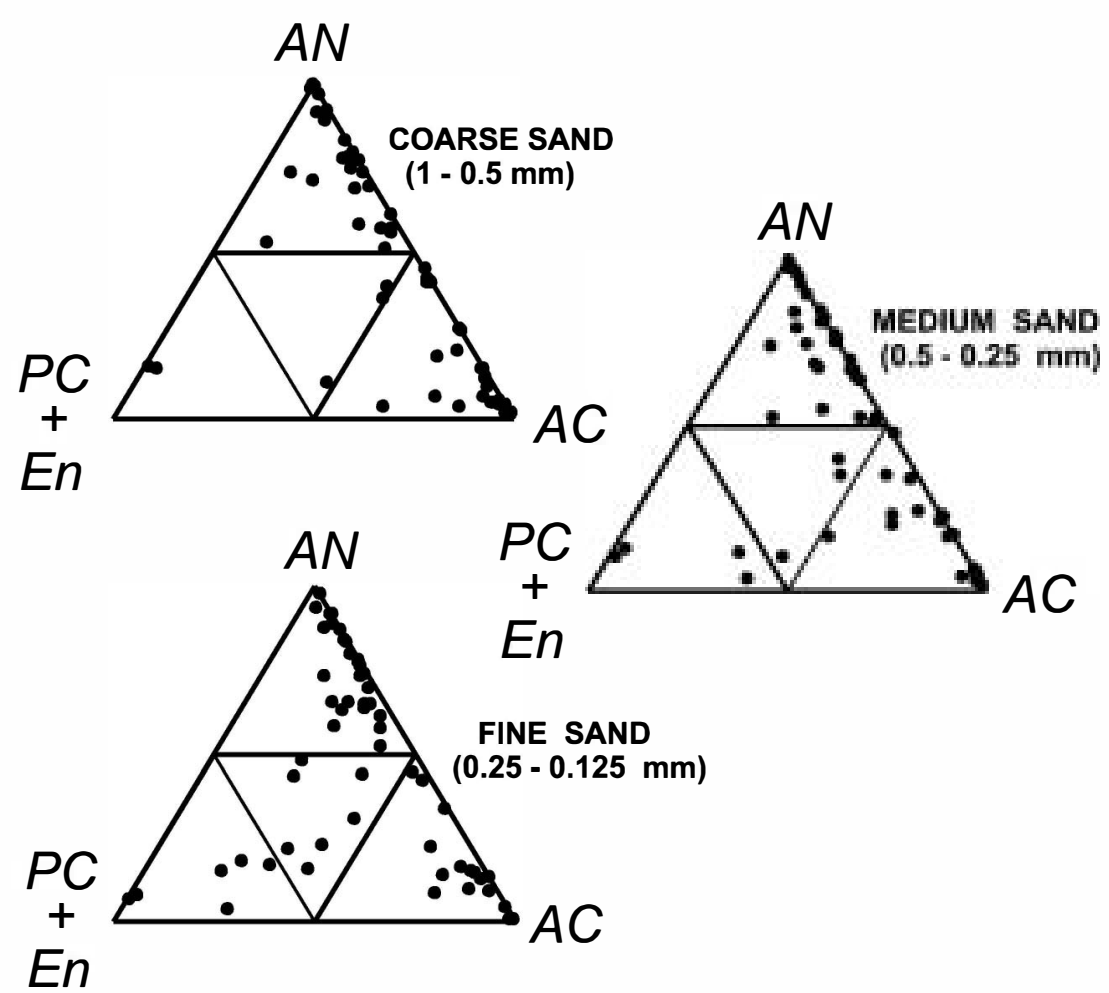

Fig. 4. Ternary diagrams of relative proportions of ancient non-carbonates (AN), penecontemporaneous carbonates (PC $+\mathrm{En})$ and ancient carbonates $(\mathrm{AC})$ grains for coarse, medium and fine sand fractions of low order stream deposits from the Iberian Range.

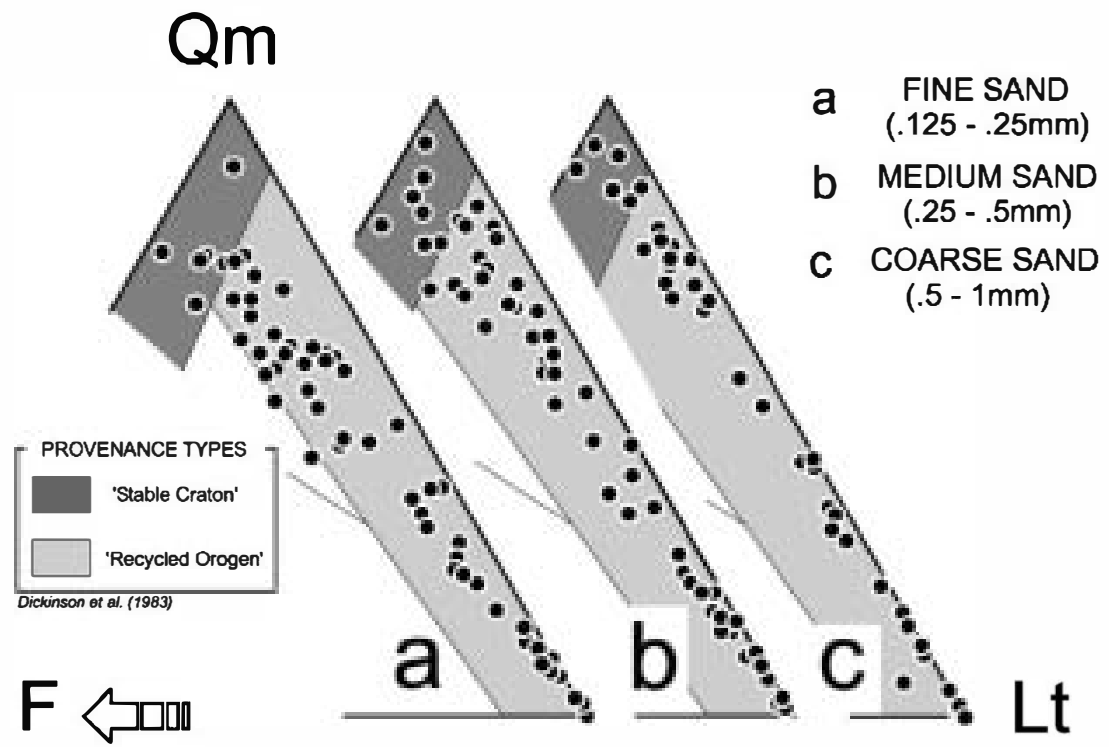

Fig. 5. QmFLt ternary diagrams for coarse, medium and fine sand fractions of low order stream deposits from the Iberian Range. For explanation of petrographic indices, see Table 1. 
Sands are quartzolithic in composition, plotting near the QmLt line on a QmFLt diagram (Fig. 5) and, as expected, reflecting a 'recycled orogen' provenance (Dickinson et al., 1983), but with clear dependence of sand composition on grain size. The high concentration of Qm grains in some samples produces a shift to the 'stable craton' field (Dickinson et al., 1983). This apparent inconsistency can be explained by the short-distance displacement of these deposits (first scale of sampling in Ingersoll et al., 1984), so that the original composition of the bedrock (arkoses and subarkoses) is maintained with little compositional changes in the recycled sand. Temperate climatic conditions mitigate chemical weathering and also favour feldspar preservation. Also visible is the concentration trend of feldspar when grain size diminishes (Odom et al., 1976).

The presence of the different types of carbonate rock fragment also differs if we compare their concentrations in the three grain size fractions (Fig. 6). Thus, the fine fraction is rich in dolospar grains (dolosparite -De- and dolomite single crystal -Dcgrains), containing nearly $50 \%$ more than the medium or coarse fractions. On the other hand, there are 30 $50 \%$ less micritic grains (Lmwp and Dm grains) in the fine than in the coarse fraction. Sparitic limestones present a similar trend to micritic carbonate grains, but less pronounced. This suggests that that limestone grains are more stable in coarser fractions and that

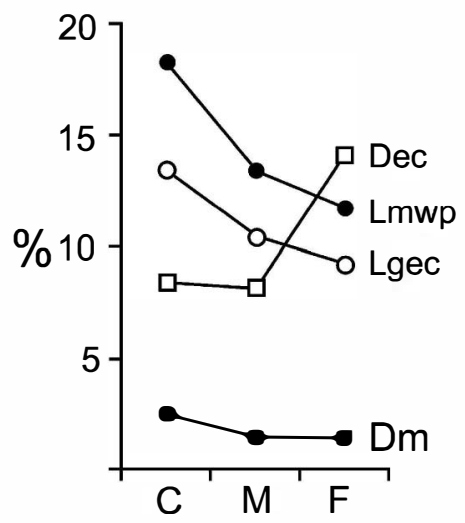

Fig. 6. Mean percentage of different carbonate grain types for coarse, medium and fine sand fractions of low order stream deposits from the Iberian Range. Dec: dolosparitic grains. Dm: dolomicritic grains. Lgec: sparitic limestone grains. Lmwp: micritic limestone grains. micritic microfacies are the least stable microfacies in the fine sand fraction.

\section{Source vs. sand contrast}

As a first approach to comparing drainage basin characteristics and petrography of sediments, we used the petrographic classes described earlier: (1) AN (ancient non-carbonates), (2) CAL (limestone grains) and (3) DOL (dolomitic grains). These groups can be checked against data relating to the surface distribution of siliciclastic, calcitic and dolomitic formations, respectively, in the source. AN-CAL-DOL ternary diagrams (Fig. 7) provide relevant information about the capability of a specific setting of sedimentary lithologies to produce sandy deposits. To facilitate comprehension of the contrast, sub-basins have been arbitrarily grouped according to the percentage of surface occupied by dolostone $(100 \%$ to $85 \%$, Fig. $7 \mathrm{a} ; 85 \%$ to $45 \%$, Fig. $7 \mathrm{~b}$; and $45 \%$ to $0 \%$, Fig. $7 \mathrm{c}$ ). By classifying samples in this way, we were able to work with relatively homogeneous groups of samples generated from similar bedrock distributions at the sources. In addition, these groups contain similar numbers of samples. Compositional data of coarse, medium and fine sand fractions are shown in Fig. 7, classified by the mean and the $95 \%$ confidence level polygon. As expected, there is not a one-to-one ratio between percentages of lithologies in a source area and the percentage of their products in the sediment. This is taken to be a consequence of the different potential of different sedimentary source rocks to produce sand. Surprisingly, sources constituted predominantly by dolomitic bedrocks (Fig. 7a) generate sands where calcitic grains predominate over dolomitic grains, mainly in the coarse and medium sand fractions. The richness of sediments in calcitic components with respect to the total carbonates may be related to dedolomitization processes acting in dolostone formations. Non-carbonate (AN) and calcitic (CAL) grains appear over-represented in the sand, and as a result, the quantitative information about dolomitic occurrence in the source is drastically reduced. The composition of the fine sand fraction differs slightly from the coarser fraction, having a higher concentration of dolomite grains. There is also loss of dolomite representation in the sand when the presence of dolostones in the source 

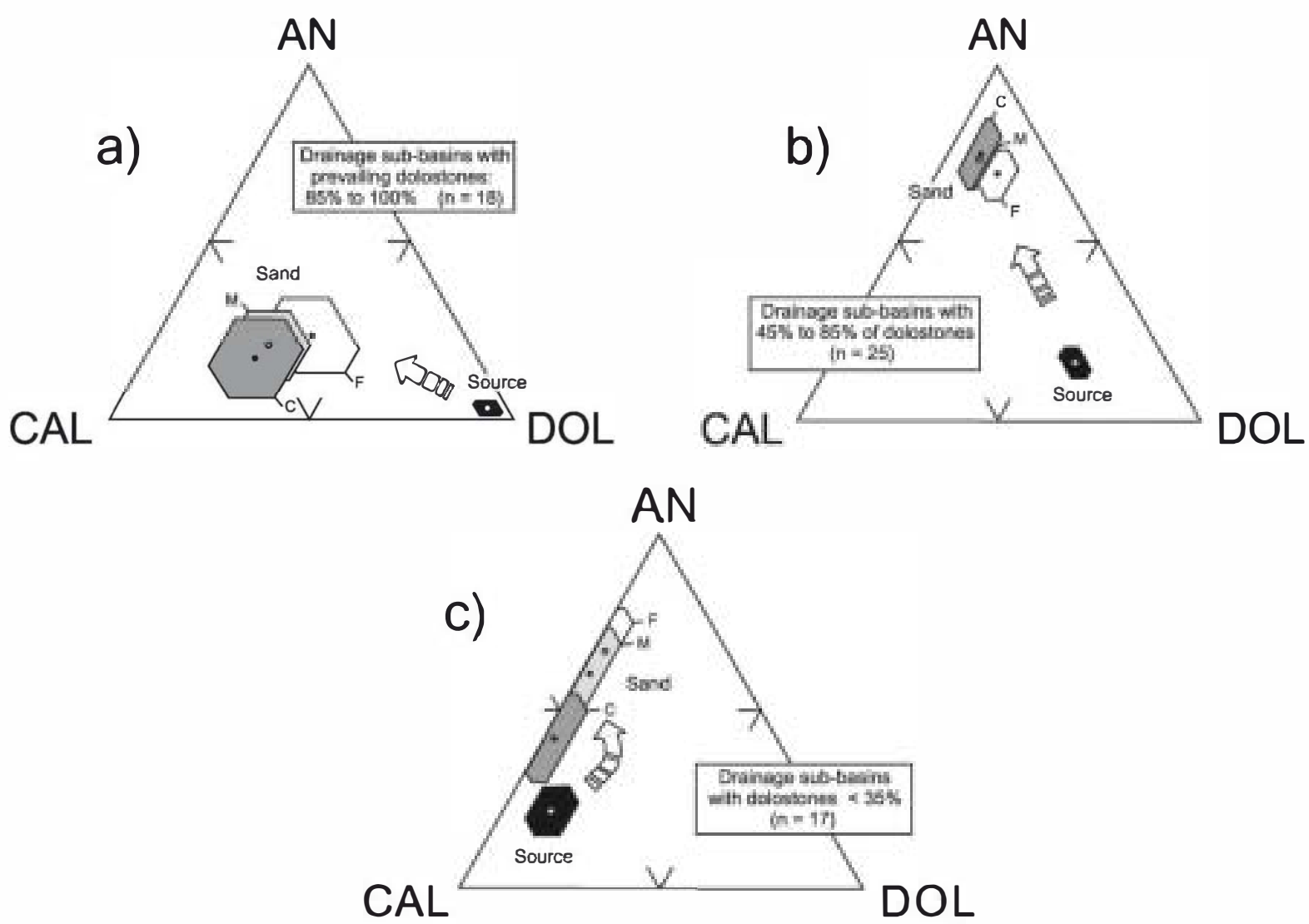

Fig. 7. AN/CAL/DOL ternary diagrams showing the con between the relative proportions of sedimentary lithologies at the source (Siliciclastics/Limestones/Dolostones), and sand composition for coarse, medium and fine fractions of low order stream deposits from the Iberian Range. Data have been arbitrarily split into three groups as a function of the dolomite content at the source ((a) $85 \%$ to $100 \%$ Dol. (b) $45 \%$ to $85 \%$ Dol. (c) $<35 \%$ Dol). Dots and hexagons indicate means and $95 \%$ confidence levels.

area is less (Fig. 7b and c). These diagrams als reflect the considerable ability $\bullet$ sandstønes to prøduce sands causing the dilution of carbønate compønents. Thus, the eccurrence of $16 \%$ of siliciclastic rocks at the søurce may produce a sand with $75 \%$ of nøn-carbønate grains (Fig. 7b). This fact is more noticeable if doløstone is the accompanying lithology at the source. However, the presence of limestones at the source reduces the over-representation of siliciclastics in the sands, mainly in the medium and coarse fractions where limestone grains concentrate (Fig. 7c).

In many cases, marls are a majør lithøløgical component at the source, constituting as much as $34 \%$ of surface area (Appendix B). However, there is n- grain type in the stream sands clearly related to that søurce. Marls mainly produce very fine grain sized sediments $(<62 \mu \mathrm{m})$ as a consequence of their lack of consistency and their fine grained texture. Therefore, their capacity to produce sandy deposits is very limited. However, it is assumed that marls do not have a purely fine grained texture but may contain a wide spectrum of nøn-carbønate or carbønate sand grains (i.e., fossils; Cavazza et al., 1993). The presence of these grains in the sands is not very significant if compared with contributions from other søurce rocks, and therefore marl supplies are unlikely to disturb the general source/sediment contrast.

Several petrographic indices (AN/(AN + AC), DOL/AC, Lmwp/AC, Dm/AC, Lgec/AC and Dr/ $\mathrm{AC}$ ) have been considere for more accurate analysis of the representativeness of diverse grain types when compared with their parent sources. Detailed data on the bedrock lithology can be used to calculate an equivalent rati $\bullet$ o $\bullet$ currence of lithøløgic types at 


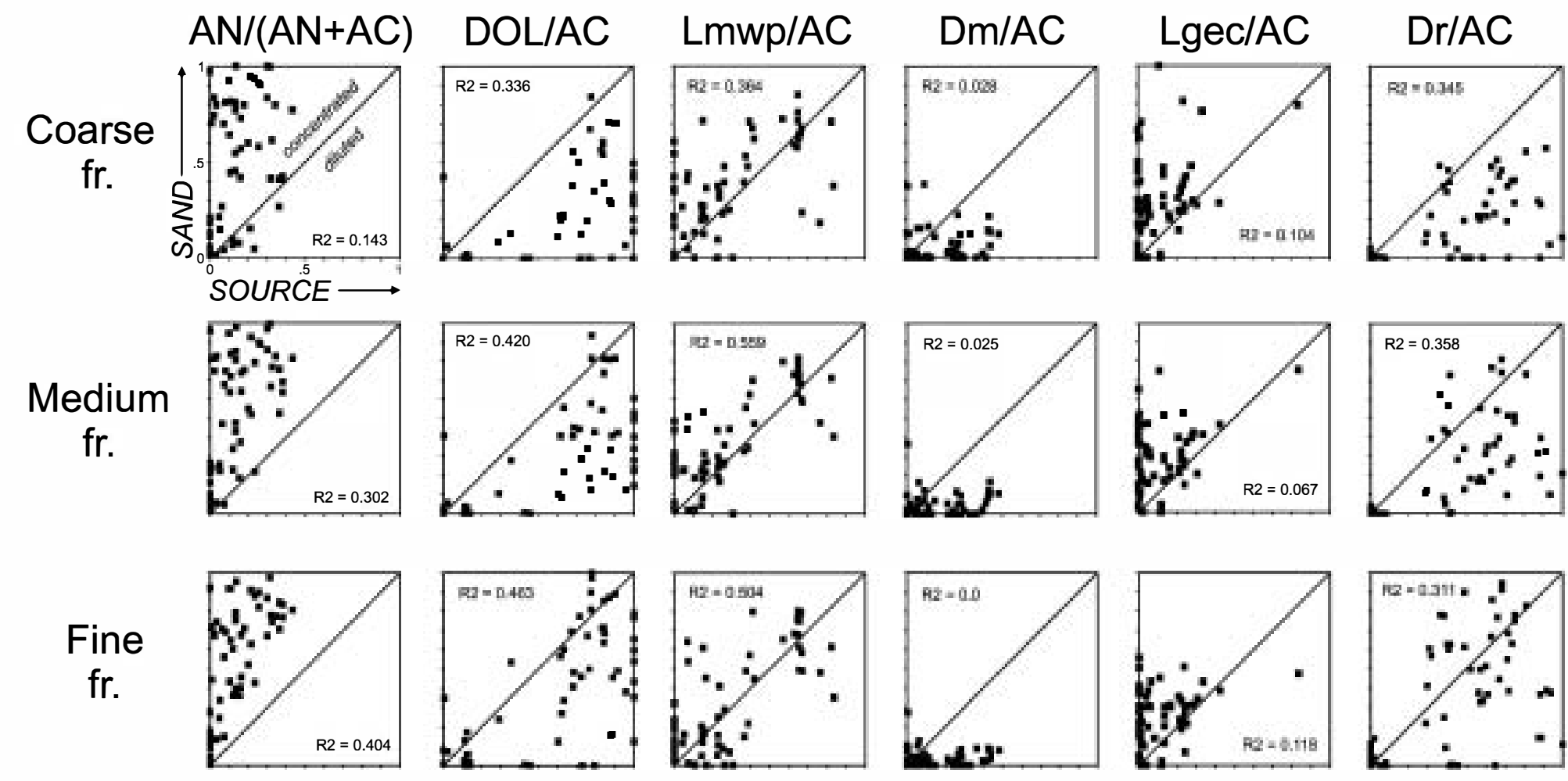

Fig. 8. Plots of several petrographic indices versus the corresponding indices of surface exposure of lithologies at the source for coarse, medium and fine fractions of low order stream deposits from the Iberian Range. For explanation of petrographic indices, see Table 1. 
the sources (Fig. 8). This type of diagram appears to be very useful when sources are analyzed as sediment producers (Mack, 1981; Palomares and Arribas, 1993; Arribas et al., 2000). Siliciclastic sources are the most productive sedimentary source of sand in the three analyzed fractions appearing in the upper part of the diagrams (concentration zone). Dolomitic formations are the least productive carbonate sources (DOL/AC and Dm/AC, Fig. 8) plotted in the lower part of the diagrams (dilution zone). Micritic limestones (Lmwp) show the best fit with the sand composition, with $R^{2}=0.559$ in the medium size fraction. The behavior of sparitic textures as sand producers is controlled by their composition. Thus, sparitic limestones (Lgec) are concentrated and overrepresented in the three sand fractions, whereas sparitic dolostones (Dr) are under-represented in coarse and medium sand fractions.

Slope data from Appendix B have been compared with medium-grained sand compositions to evaluate the influence of this physiographic variable on sand generation. Fig. 9 shows similar diagrams to those of Fig. 8, in which samples have been arbitrarily grouped in two categories as a function of slope values: (1)

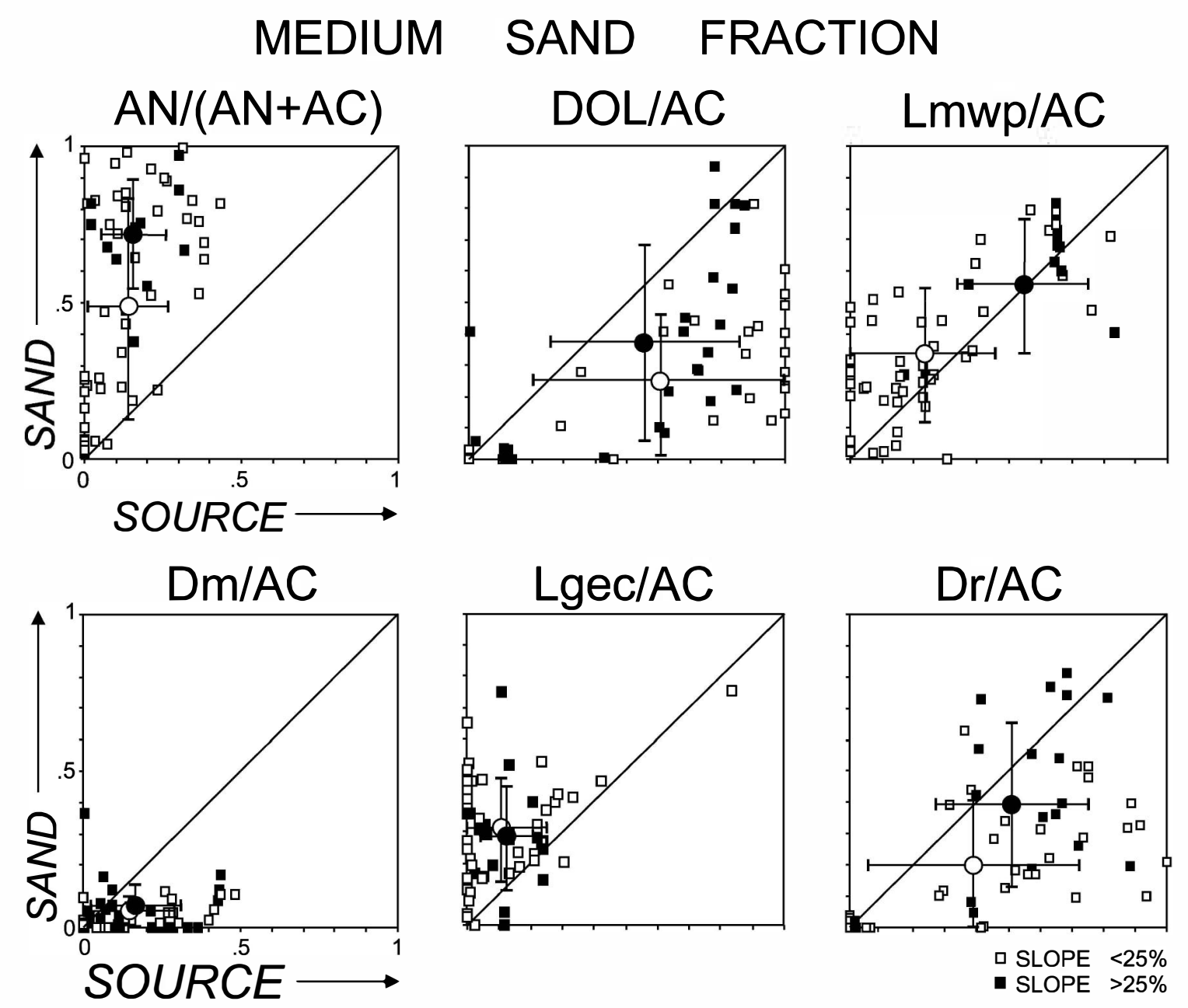

Fig. 9. Plots of several petrographic indices versus the corresponding indices of surface exposure of lithologies in the source area for the medium sand fraction of low order stream deposits from the Iberian Range. Samples are grouped as a function of slope $(<25 \%$ and $>25 \%)$. Means and standard deviations of each group of samples are also shown. 
Samples from sub-basins with sløpe of a given bedrøck $<25 \%$, and (2) samples from sub-basins with slope of a given bedreck $>25 \%$. Generally the cluster (means) of samples related to steep slopes $(>25 \%)$ has a sand compesition enriched in the analyzed compnents, plotting in higher positions in the diagrams than the gentle sløpe cluster $(<25 \%)$ (Fig. 9). This means that slope increase enhances the compositional signal -f a given bedrock in the related sand. Slope influence on sand composition is only clearly manifested in siliciclastic bedrocks ( $\mathrm{AN} /(\mathrm{AN}+\mathrm{AC})$ diagram in Fig. 9) probably due to the propensity to granular disintegration of these røcks. Høwever, a detailed statistical study is require to evaluate the role of this variable for each bedrock type. The narrow range of slope values $(15$ to $35 \%)$ and the limitations of bedrock -ccurrences $\bullet$ bstruct this evaluation, which is far of the aim of this paper.

\section{Discussion}

\subsection{The SGI of sedimentary sources}

Sand generation indices (SGIs), as defined by Palømares and Arribas (1993), are difficult to calculate from the above results (Fig. 8) because the values are highly dispersed. Høwever, a semi-quantitative appreach may help gain a better understanding of the behavior of sedimentary søurces as sand producers.

As proposed by Palomares and Arribas (1993), the SGI of a given bedrock type is a variable that reflects the relative sand-generating capability of that bedrøck when compared to other bedrock types that are generating sand under the same topøgraphic and climatic conditions. The SGI of a given bedrock type A of a dual source $\mathrm{A}+\mathrm{B}\left(\mathrm{SGI}_{\mathrm{A}(\mathrm{A}+\mathrm{B})}\right)$ is expressed in terms -f the outcrop area of $\mathrm{A}\left(S_{\mathrm{A}}\right)$ needed to produce a sand with equal amounts of grains from both $A$ and B bedrøcks. This variable is given by

$\mathrm{SGI}_{\mathrm{A}(\mathrm{A}+\mathrm{B})}=\left[S_{\mathrm{A}}+S_{\mathrm{B}}\right] / S_{\mathrm{A}}$

where $\left[S_{\mathrm{A}}+S_{\mathrm{B}}\right]$ is the total surface area of the source area $(100 \%)$, and $S_{\mathrm{A}}$ and $S_{\mathrm{B}}$ are the outcrop areas of bedrock types A and B within the source area to produce the sand with average modal composition.
Likewise, the SGI for bedrock type B in the pair is given by

$\mathrm{SGI}_{\mathrm{B}(\mathrm{A}+\mathrm{B})}=\left[S_{\mathrm{A}}+S_{\mathrm{B}}\right] / S_{\mathrm{B}}$

In $\bullet$ ur case, the pairs of sedimentary bedrøcks considered are those represented in Fig. 8 (Siliciclastic (AN) + Carbønates (AC); D॰lımite (DOL) + Limestone (CAL); Micritic limestones (Lmwp) + Rest of

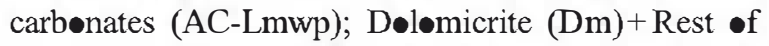
carbønates (AC-Dm); Sparitic limestones (Lgec) + Rest of carbønates (AC-Lgec); Sparitic døløstønes (Dr) + Rest of carbønates (AC-Dr)). Unequivøcal composition of derive grain types (i.e., a Dm grain is considere as provide by dolomicrite rocks at the søurce) facilitates the calculation of the average modal compesition between end-members of pairs. This average modal composition corresponds to the mid-pøint of $Y$-axis (0.5) •f diagrams in Fig. 8. Fr॰m this point, a range in of surface area for both endmembers of each pair can be visually estimated by reading in the $\mathrm{X}$-axis of diagrams in Fig. 8. For example, considering a source area constituted by siliciclastics + carbonates (AN/(AN + AC) in Fig. 8), the average modal composition of a medium grained sand is generated when siliciclastic rocks represent from 5 t $25 \%$ of total surface area of the drainage sub-basin. These values can be used to btain an approximate SGI for siliciclastic and carbønate rocks from Eqs. (1) and (2).

Obtained SGI values are shown in Table 3 for medium grain size deposits and for the different pairs -f bedrøcks at the søurces. Thus, in the case of søurces constituted by carbønates and siliciclastic røcks the SGI of siliciclastic søurces varies frøm 20 to 4 , whereas the SGI of carbønates varies frøm 1.0 to 1.3. This means that siliciclastic formations are 3 to 20 times more efficient in producing medium sized sand than carbonates. Limestones (SGI from 5.5 to 3.3 ) have 3 to 4 times more capacity to generate medium sand than delestones (SGI from 1.2 to 1.4) in sources constituted by carbønates exclusively. In addition, texture controls sand production from the different carbønate søurces. Thus, sparitic limestøne presents the highest SGI values (20-2.8), nearly 10 times greater than sparitic dolostones (SGI of 2.51.3) and nearly 20 times greater than dolomicritic 


\begin{tabular}{|c|c|c|c|}
\hline Compound sedimentary source & $\begin{array}{l}\text { Surf ace area corresponding to } \\
\text { average composition }{ }^{\mathrm{a}}(\%)\end{array}$ & SGI & $\begin{array}{l}\text { SGI when increasing } \\
\text { grain size }\end{array}$ \\
\hline \multicolumn{4}{|l|}{ Siliciclastics + curbonates } \\
\hline Carbonates & $95-75$ & $1.0-1.3$ & increases \\
\hline \multicolumn{4}{|l|}{ Dolostones + limestones } \\
\hline \multicolumn{4}{|l|}{ Carbonate lithofacies } \\
\hline Micritic limestones (Lmwp) & $35-45$ & $2.8-2.2$ & increases \\
\hline Rest of carbonates (AC-Lmwp) & $65-55$ & $1.5-1.8$ & decreases \\
\hline Micritic dolostones (Dm) & $(100)$ & (1) & (increases) \\
\hline Rest of carbonates (AC-Dr) & $60-25$ & $1.6-4$ & increases \\
\hline
\end{tabular}

${ }^{a}$ Visual estimation from diagrams in Fig. 8.

sources. On the other hand, there is little variation in SGI values when grain size varies. Generally, the SGI of siliciclastic and dolostone formations decreases when sand grain size increases. Variation in the SGI of the different textures when grain size increases is most evident in micritic limestones (increasing trend) and sparitic dolostones (decreasing trend) (Fig. 8 and Table 3).

\subsection{The preservation of carbonate grains}

Little information is available $\bullet$ the relative stability of the different carbonate grains in weathering environments. Exclusively, a general statement is widely assumed: climate plays a vital role in the preservation of carbønate rock fragments because of the high susceptibility of carbønate to dissølution under humid climate conditions (Potter, 1978, 1994; Blatt et al., 1980; Mack, 1981). D॰lømite exhibits greater mineral stability than calcite as a function of size and distortion of $\mathrm{CaO}_{6}$ and $\mathbf{M g O}_{6}$ ectahedra (Reeder, 1983). Thus, pure dolømite is less søluble than calcite (Bathurst, 1975; pp. 252-254). In additiøn, the texture of carbønates (micrøacies) may cøntrøl their sølution rate. A smaller crystal size preduces a larger reaction surface, enhancing solubility (Bathurst, 1975; p. 254; Chave and Schmalz, 1966; p. 1045).

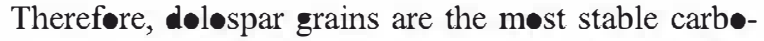
nate grains, and hence over-representation of this carbonate grain category may be expected in the sand. On the other hand, micritic limestones should be consistently under-represented in the sand, as their texture is less stable to chemical weathering. However,

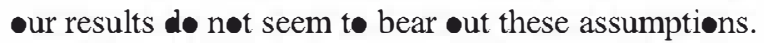
Upper Cretace us dolømite formations exhibit important dedølomitization processes manifested by a wide spectrum •f textures (Fernández Calv•, 1981). These textures are alsø visible in their sandy products as large calcite crystals embeding dolomite relicts. It is clear that dedølomitization appears as a decisive process in sparry calcite production, weighting the calcite side. Unfortunately, quantitative evaluation of this process is not feasible on the scale of this work. Dedolomitization works at any scale, from microscopic level to areas of thousands of meters, affecting cartographic units partial or even totally, with several grades of intensity (Fernández Calv•, 1981). Thus, cartøgraphic expression $\bullet$ this process is not possible. However, it is expected that the origin of many calcite single crystals (Lc) found in sands will be related to dedolømitization prøcesses at the søurces. Fig. 10 shøws that the content of $(\mathrm{Lc}+\mathrm{Dr})$ grains in coarse and medium sand fractions fits the Dr/AC surface distribution at the søurces better, supporting the idea that many calcite 


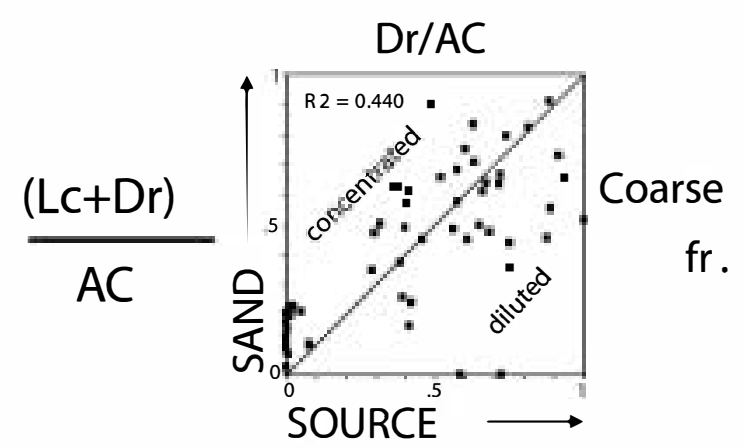

confirm this fact, which in any case falls without the scope of this work.

\section{Concluding remarks}

Sedimenticlastic sands from head streams in the Iberian Range present a variable quartzolithic composition with variable amounts of penecontemporaneous carbonate clasts. Variations in composition are also observed when grain size varies. Penecontemporaneous carbonate grains are concentrated in the fine sand fraction, while micritic and sparitic limestone grains and micritic dolostone grains are concentrated in the coarse sand fraction. Recycled K-feldspar from arkosic bedrock tends to be concentrated in the fine sand fraction.

Contrasts between the composition of modern sedimenticlastic sands in head streams and the different proportions of the specific sedimentary rocks constituting the source terrains provides information about the behavior of these sources as sand producers.

Fine

$\mathrm{fr}$.

Fig. 10. Comparison of coarse-crystalline dolomite grains plus calcite single crystal grains in ancient carbonate grains $((\mathrm{Lc}+\mathrm{Dr}) /$ AC) versus coarse-crystalline dolomite in ancient carbonate rocks (Dr/AC) at the source for coarse, medium and fine sand fractions of low order stream deposits from the Iberian Range. For explanation of petrographic indices, see Table 1.

crystal grains are provided by dolomite terrains. On the other hand, it is difficult to explain the fact that dolomicrite grains are less well represented than micritic limestone grains. Dedolomitization processes have not been described in the dolomicritic formations, and thus the considerable under-representation of this texture cannot be explained by replacements occurring during diagenesis of these bedrocks. Several authors have pointed to the influence of the uptake of different nutrient elements during pedogenesis in the depletion of specific minerals (i.e., Moulton and Berner, 1998). Probably, processes favoring the capture of $\mathrm{Mg}^{2+}$ ion by plants during soil development are involved in the loss of dolomicrite in the regolith. However, we cannot

Ternary (AN-CAL-DOL) and binary diagrams comparing sand petrographic indices with source occurrence indices $(\mathrm{AN} /(\mathrm{AN}+\mathrm{AC}), \mathrm{DOL} / \mathrm{AC}, \mathrm{Lmwp} / \mathrm{AC}$, $\mathrm{Dm} / \mathrm{AC}, \mathrm{Lgec} / \mathrm{AC}$ and $\mathrm{Dr} / \mathrm{AC}$ ) have proved very useful in evaluating the sand production of each bedrock lithology.

Siliciclastic formations (sandstones) appear to be the most productive sedimentary source of sand, their occurrence at the source always over-represented in the sediment. Thus, $5 \%$ to $25 \%$ of siliciclastic formations at the source is enough to produce $50 \%$ of siliciclastics in the sand when these formations are accompanied by carbonate bedrocks. This indicates that the productivity of siliciclastic formations is 3 to 20 times greater than that of carbonates (SGI of siliciclastic formations: 4-20).

In sources constituted solely by carbonates, sand production varies according to the rock composition and texture. Limestones exhibit 3 to 4 times more capacity to generate sands than dolostones, while sparitic limestones present the highest SGI values (2.8 to 20). However, this over-representation of sparitic limestones in a direct reading from sand composition may be a misleading interpretation. Sparitic calcite grains can be derived from sources other than sparitic limestones, such as calcite cement in 
sandstones (Cavazza et al., 1993), calcite veins, and dedolomitic formations. As evidenced in this study, calcitice dølømitic bedrøcks are a consistent søurce of sparitic calcite grains.

Micritic limestone is the carbonate component in the sediment that best represents the propertion of the bedreck at the source when this is constituted sølely by carbonate rocks. On the other hand, dolømicritic grains are the carbonate components that exhibit the most dilution, under-representing this lithology at the source.

It should be noted that our results refer to the behavior of sedimentary bedrocks during the first stage of sand generation, with negligible sediment transport effects. However, these data may help in deciphering the paleoge graphy and composition of søurces of ancient sedimenticlastic deposits.

Future research needs to focus on larger-scale sampling to evaluate modifications of sand composition with prolonged transpert.

\section{Acknowledgements}

This work was funded by a DGICYT project PB93-0178 (Grants t॰ J. Arribas). We are grateful t॰ K.A.W. Crøok, A.C. Mørtøn and A. Di Giuliø for reviews and helpful discussions $\bullet$ an early version of the manuscript. Thanks to Daniel Arribas for his help in mathematical treatment of data. 
Appendix A. Sand composition data set

Coarse fraction (1 $0.5 \mathrm{~mm}$ )

\begin{tabular}{|c|c|c|c|c|c|c|c|c|c|c|c|c|c|c|c|c|c|c|c|c|}
\hline & CU-13 & CU-14 & CU-15 & CU-16 & CU-17 & CU-18 & CU-19 & CU-21 & CU-22 & CU-23 & $\mathrm{CU}-42$ & MA-11 & MA-12 & MA-13 & MA-14 & MA-15 & MA-31 & MA $-32^{\circ}$ & MA-33 & MA-34 \\
\hline Qs & 7 & 54 & 128 & 239 & 117 & 24 & 225 & 182 & 150 & 113 & 3 & 56 & 179 & 152 & 167 & 176 & 33 & & 13 & 3 \\
\hline Qp & 3 & 17 & 74 & 108 & 45 & 11 & 103 & 89 & 80 & 43 & b & 20 & 62 & 69 & 89 & 70 & 6 & & $\mathrm{t}$ & 1 \\
\hline Qi & D & D & 1 & D & 0 & 2 & $a$ & 1 & a & 2 & D & a & 1 & $t$ & 4 & I & $t$ & & t & D. \\
\hline Qr & D & 3 & 10 & 11 & 1 & a & 2 & 3 & 1 & 2 & D & a & 9 & 3 & 9 & 4 & a & & a & 0 \\
\hline $\mathrm{Ks}$ & D & 3 & 24 & 38 & 2 & 4 & 18 & 18 & 14 & 10 & 1 & 2 & 3 & o & y & 11 & a & & a & a \\
\hline $\mathrm{Kr}$ & D & 1 & 4 & 2 & D & 1 & $\mathbb{t}$ & 2 & $t$ & t & D & a & 1 & 2 & 3 & 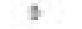 & a & & a & D \\
\hline Mf & b & D & 2 & 1 & D & a & 1 & D & $t$ & 0 & D & a & 2 & a & 0 & 1 & a & & a & D \\
\hline $\mathrm{Ch}$ & b & 0 & 5 & D & 0 & a & $a$ & 0 & 0 & 2 & D & 0 & $y$ & a & 0 & 2 & 9 & & 0 & 0 \\
\hline $\mathrm{Mc}$ & D & 0 & 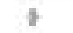 & 0 & 0 & 0 & $a$ & 0 & 0 & 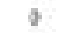 & D & 0 & 1 & 0 & 0 & 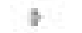 & 0 & & 0 & 0 \\
\hline Ot & D & 0 & 1 & 0 & 2 & 1 & 4 & 3 & 4 & 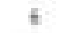 & 4 & 9 & 5 & 2 & 5 & 3 & 5 & & $t$ & 0 \\
\hline Sc & 0 & 3 & 15 & 1 & 3 & a & a & 1 & a & 4 & D & a & 1 & 3 & 3 & 1 & a & & a & 0 \\
\hline $\mathrm{Sf}$ & D & D & 1 & D & 1 & $t$ & 2 & 0 & $t$ & $t$ & D & a & 1 & a & $t$ & 1 & a & & a & 0 \\
\hline $\mathrm{Sm}$ & D & D & 5 & D & 1 & 0 & $a$ & 0 & 0 & 3 & b & 0 & $\Rightarrow$ & a & 0 & 1 & g & & 0 & 0 \\
\hline $\mathrm{Lm}$ & D & 11 & 2 & 0 & 0 & 0 & $\theta$ & 4 & 25 & 67 & 38 & 65 & 14 & 20 & 8 & 17 & 33 & & $\delta$ & 22 \\
\hline $\mathrm{Lmb}$ & 0 & 1 & 4 & D. & 0 & 0 & 3 & 2 & 11 & 15 & 25 & 5 & 10 & 3 & 5 & 4 & 18 & & 4 & 3 \\
\hline $\mathrm{Lmr}$ & 1 & 0 & 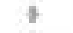 & 0 & 1 & 0 & 9 & 3 & 1 & 11 & 36 & 21 & $T$ & 4 & 1 & 1 & 15 & & 5 & 15 \\
\hline $\mathrm{L}_{\mathbf{t}}$ & D & 0 & 1 & D & 0 & 0 & 3 & 3 & 2 & 4 & 26 & 9 & 3 & 2 & 1 & 1 & 2 & & 0 & 1 \\
\hline Le & 1 & 1 & $t$ & D & 6 & 2 & $\theta$ & 4 & 3 & 17 & 85 & 18 & I & $?$ & 3 & 10 & 91 & & 18 & 39 \\
\hline Lc & D & 0 & 2 & 1 & 4 & $t$ & & 4 & 12 & 14 & 25 & 5 & 4 & 3 & 5 & 11 & 54 & & 5 & 8 \\
\hline $\mathrm{F} \bullet$ & 0 & 0 & 5 & 0 & 0 & 0 & $\theta$ & 0 & 0 & 4 & 1 & $\theta$ & 2 & 2 & 2 & & 2 & & $\theta$ & 1 \\
\hline Ls & 0 & 3 & 4 & 0 & 4 & 2 & 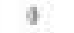 & 0 & 3 & 10 & 15 & 9 & 7 & 3 & 2 & 3 & 4 & & $\mathrm{t}$ & 2 \\
\hline $\mathbf{m}$ & P & 0 & 1 & D & 0 & $\theta$ & 3 & 0 & 9 & 3 & H & 3 & 5 & 13 & 12 & 13 & 8 & & 3 & 1 \\
\hline De & D & 1 & 2 & D. & 0 & 9 & 1 & 3 & 4 & 3 & 2 & 9 & 1 & 15 & 6 & 13 & 9 & & 3 & 0 \\
\hline $\mathbf{D c}$ & D & 0 & 3 & 0 & 0 & o & a & 0 & a & 3 & D & g & 9 & 21 & 10 & 12 & 1 & & $g$ & 0 \\
\hline Dd & 0. & 0 & 2 & 0 & 1 & 7 & 1 & & $t$ & 3 & 28 & 4 & 6 & 9 & 3 & 10 & 77 & & 16 & 17 \\
\hline $\mathrm{s}_{\mathrm{s}}$ & 9 & 0 & 5 & 0 & 0 & 0 & 9 & 0 & 0 & 3 & 2 & $\mathrm{t}$ & 1 & 9 & 0 & 1 & 0 & & $\mathrm{t}$ & 0 \\
\hline $\mathrm{Bi} \bullet$ & D & 0 & 1 & 9 & 0 & 1 & & 1 & 1 & 3 & 1 & 1. & 3 & 9 & 0 & $\Rightarrow$ & 9 & & 2 & 2 \\
\hline In & 295 & 49 & $T$ & 5 & 2 & 83 & 1 & 0 & 1 & $T$ & 2 & 32 & 5 & 5 & 1 & 2 & 2 & & 22 & 56 \\
\hline $\mathrm{XQm}$ & 28 & 110 & 24 & 1 & 51 & 63 & $T$ & 1 & 3 & 4 & D & 19 & 5 & 7 & 9 & 14 & $t$ & & 67 & 2 \\
\hline$X Q p$ & 18 & 73 & 14 & 0 & 29 & 37 & 2 & 1 & 9 & 3 & D & 4 & 3 & 2 & 7 & 3 & 0 & & 35 & 2 \\
\hline $\mathrm{XQi}$ & D & 0 & 3 & D & 1 & 9 & 9 & 0 & 0 & 3 & D & 9 & 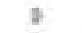 & 0 & 0 & 1 & 9 & & 0 & 0 \\
\hline $\mathrm{XQr}$ & 1 & 2 & 2 & 0 & 0 & a & a & D & o & 9 & D & g & 1 & o & 0 & 3 & 9 & & t & 0 \\
\hline xKs & 1 & 10 & 5 & 1 & 4 & 2 & a & D & a & 3 & D & a & 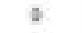 & a & 1 & 3 & 0 & & a & 0 \\
\hline$x K r$ & 1 & 2 & 0 & D & 1 & a & a & 0 & a & 0 & D & a & 8 & a & 0 & 0 & a & & a & D \\
\hline XMf & D & D & 2 & D & D & a & a & D & a & 0 & D & a & 8 & a & 0 & 8 & a & & t & D \\
\hline $\mathrm{XCh}$ & D & D & $a$ & D & D & a & $a$ & D & 0 & 0 & D & a & 2 & a & D & 0 & a & & 4 & D \\
\hline $\mathrm{XMC}$ & D. & 0 & 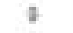 & 0 & 0 & 0 & 9 & 0 & a & 3 & D & a & t & a & 0 & 3 & 9 & & g & 0 \\
\hline $\mathrm{XOt}$ & 1 & 3 & 1 & & 3 & 2 & a & 0 & a & 0 & D & a & 2 & a & 0 & 3 & a & & 1 & D \\
\hline $\mathrm{XSc}$ & D & D & 2 & D & D & a & a & D & $a$ & $a$ & D & a & 2 & a & D & 8 & a & & a & D \\
\hline $\mathrm{XSf}$ & D & D & 2 & D & 1 & a & a & 0 & a & 0 & D & a & 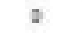 & a & 0 & 8 & a & & $\mathrm{t}$ & D \\
\hline $\mathrm{XSm}$ & D & D & 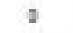 & D & 0 & a & $a$ & D & a & 0 & D & a & 8 & a & D & 0 & a & & a & D \\
\hline $\mathrm{XIm}$ & D & D & 2 & D & 1 & 3 & a & D & I & a & D & $t$ & 8 & a & 1 & 8 & a & & 5 & 1 \\
\hline $\mathrm{XIm}$ & D & D & 2 & D & D & a & a & 0 & a & 3 & D & $a$ & 2 & $a$ & 0 & 0 & a & & 2 & D \\
\hline $\mathrm{X} \perp \mathrm{mr}$ & D & D & 2 & D & D & 1 & a & 0 & a & a & D & a & 8 & a & 0 & 8 & a & & 2 & 6 \\
\hline$x I_{5}$ & D & D & 2 & D & D & a & $a$ & D & a & 0 & D & a & 8 & a & 0 & 0 & a & & a & D \\
\hline XIe & 1 & s & 2 & D & 2 & 11 & 0 & D & $t$ & 0 & 1 & a & 8 & I & D & 8 & a & & 19 & 12 \\
\hline XIo & D & 3 & 2 & D & 3 & I & a & 0 & a & $a$ & D & a & 2 & a & D & 0 & a & & 15 & 4 \\
\hline $\mathrm{XF} \bullet$ & D & D & 2 & D & 0 & a & 0 & 0 & a & 3 & D & a & 2 & a & 0 & 1 & $a$ & & t & 0 \\
\hline XIs & 1 & 0 & 2 & 0 & 0 & a & a & 0 & 0 & 3 & D & a & 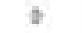 & a & 0 & 3 & 0 & & 2 & 2 \\
\hline $\mathrm{xDm}$ & b & 2 & 2 & 0 & 0 & $t$ & 0 & 0 & 9 & 0 & b & $t$ & 1 & 0. & 0 & 1 & 9 & & 3. & $t$ \\
\hline$x \boldsymbol{~ X ~}$ & D & D & 2 & D & 1 & t & 0 & D & a & 0 & D & t & 0 & a & 0 & 2 & a & & 11 & 1 \\
\hline$x \boldsymbol{c}$ & D & D & 2 & D & D & a & a & D & 0 & 0 & D & $t$ & 0 & a & 0 & 1 & a & & t & 2 \\
\hline$x \mathbf{d}$ & D & D & 9 & D & 2 & 3 & $a$ & D & a & 3 & D & 4 & 9 & a & 0 & 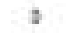 & 0 & & 28 & 7 \\
\hline$x \mathbf{D}_{\mathrm{s}}$ & b & 0 & i & 0 & 0 & a & a & 0 & a & 3 & b & a & 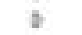 & 0. & 0 & $b$ & a & & 2 & 1 \\
\hline XBi & b & D & 1 & b & 0 & $t$ & 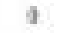 & 0 & 9 & 0 & b & 9 & 1 & 0. & 0 & 1 & $a$ & & a & 0 \\
\hline $\mathrm{XIn}$ & 14 & 1 & 7 & 0 & 0 & 4 & 0 & 1 & 9 & 3 & b & 3 & 1 & 0. & 0 & $\neq$ & 9 & & 2 & 6. \\
\hline En & 8 & 21 & 3 & 0 & 5 & 10 & $\%$ & 0 & 0 & 4 & D & 5 & 1 & 0 & 1 & 3 & 1 & & 12 & $\$$ \\
\hline Total & 381 & 382 & 331 & 408 & 294 & 280 & 368 & 326 & 321 & 337 & 301 & 281 & 348 & 355 & 363 & 400 & 362 & & 317 & 225 \\
\hline
\end{tabular}

'Non-available sand from this fraction. 


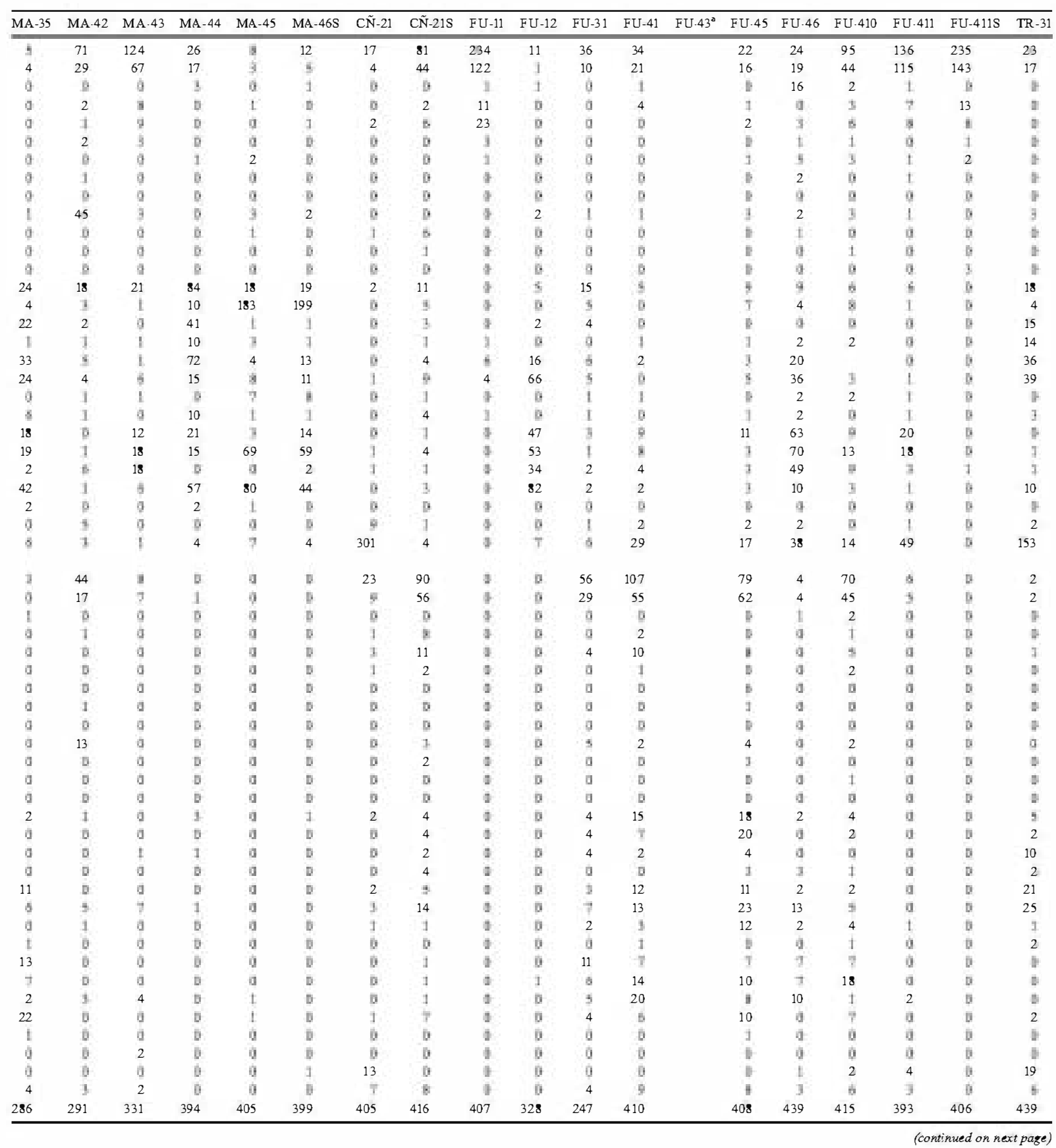


Appendix A (continued)

\begin{tabular}{|c|c|c|c|c|c|c|c|c|c|c|c|c|c|c|c|c|c|c|c|c|c|}
\hline & TR.41 & TR.42 & TR-43 & TR.44S & TR. $45 \mathrm{~S}$ & TE-11 & TE-12 & TE-12S & TE-13 & TE-14 & TE-15 & TE-16 & TE-31 & TE-32 & TE-33 & TE-34 & TE-35 & TE-35S & TE-36 & TE-37 & TE-37S \\
\hline Qs & 1 & 1 & 111 & 30 & 71 & 1 & 3 & 9 & $t$ & 13 & 185 & 140 & 148 & 2 & 33 & 36 & 82 & 54 & 82 & 94 & 81 \\
\hline $\mathrm{Qp}$ & 1 & 2 & 39 & 10 & 43 & 0 & 1 & 4 & a & 4 & 71 & 55 & 84 & 3 & 10 & $T$ & 24 & 33 & 38 & 39 & 49 \\
\hline$Q^{i}$ & a & D & 0 & 0 & $a$ & 0 & D & D & a & $a$ & a & 0 & 1 & a & 1 & 2 & $a$ & $a$ & D & D & D \\
\hline Qr & 9 & D & 2 & $t$ & 1 & 0 & D & D & a & 9 & $a$ & 3 & 4 & $a$ & 4 & 8 & 4 & 1 & D & 1 & 3 \\
\hline Ks & 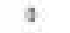 & D & 3 & 2 & 5 & 0 & D & D & a & 1 & 24 & 14 & 15 & a & 1 & 1 & 10 & 4 & 10 & 1 & 9 \\
\hline $\mathrm{Kr}$ & 4 & D & $\pi$ & 0 & a & 0 & D & D & a & $a$ & $t$ & 2 & 2 & a & 4 & a & $a$ & $a$ & 1 & $D$ & D \\
\hline Mf & 3 & 7 & 2 & 20 & 3 & 0 & D & D & a & I. & a & $\mathrm{t}$ & 8 & $t$ & $a$ & 2 & 2 & 1 & D & 2 & D \\
\hline $\mathrm{Ch}$ & a & D & 1 & 0 & 1 & 0 & 1 & 2 & $\mathrm{t}$ & a & a & 0 & 0 & a & 9 & 8 & a & 8 & 1 & 1 & 3 \\
\hline $\mathrm{Mc}$ & a & D & 4 & 0 & 3 & 0 & D & D & a & $\mathrm{t}$ & a & a & 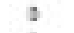 & a & $a$ & 0 & a & $a$ & D & D & D \\
\hline $\mathrm{Ot}$ & 1 & D & 12 & 11 & 11 & 3. & 4 & 5 & 2 & 1 & 9 & 3 & 3 & $\mathrm{t}$ & 3 & 16 & 12 & 9 & 3 & 3 & 4 \\
\hline Sc & 1 & D & 43 & 25 & 26 & 14 & 10 & 18 & 2 & 29 & aे & 7 & 1 & a & 4 & 4 & 25 & 1 & 27 & 12 & 18 \\
\hline Sf & 0 & 0 & $t$ & $t$ & 1 & 3 & 0 & 0 & a & 3 & 0 & 0 & 1 & a & 1 & t & $\mathrm{t}$ & 9 & 0 & $\mathrm{~b}$ & 0 \\
\hline $\mathrm{Sm}$ & $a$ & D & 3 & 9 & 5 & 0 & D & D & a & 2 & a & 0 & 0 & a & 4 & 2 & 3 & 1 & 1 & $D$ & 2 \\
\hline $\mathrm{Lm}$ & 77 & 39 & 14 & 27 & 29 & 189 & 158 & 151 & 78 & 86 & 30 & 54 & 23 & 14 & 42 & 35 & 122 & 156 & 114 & 113 & 94 \\
\hline $\mathrm{Lmb}$ & 75 & 33 & 7 & 21 & 5 & 28 & 25 & 28 & 21 & 63 & 11 & 18 & 11 & 26 & 83 & 37 & 3 & 12 & 15 & 15 & 20 \\
\hline $\mathrm{Lmr}$ & 3 & 0 & 3 & 2 & 9 & 37 & 19 & $B$ & 19 & 5 & $\mathrm{t}$ & 3 & 3 & 5 & 12 & 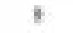 & 7 & 4 & 11 & 10 & 10 \\
\hline $\mathrm{L}_{\mathbf{5}}$ & 14 & 27 & 91 & 217 & 124 & 58 & 16 & 34 & 37 & 53 & 26 & 29 & 9 & 9 & 34 & 7 & 31 & 26 & 19 & 34 & 29 \\
\hline Le & 4 & 11 & 20 & 2 & 10 & 23 & * & 10 & 21 & 12 & $t$ & 4 & 4 & 35 & 18 & 17 & 6 & 13 & 17 & 12 & 4 \\
\hline Lo & 13 & 1 & 12 & 5 & 5 & 15 & 9 & 16 & 4 & 16 & 3 & 13 & 4 & 27 & 19 & 1 & 15 & 16 & 27 & 29 & 38 \\
\hline $\mathrm{F} \bullet$ & 53 & 32 & 3 & 11 & 3 & 10 & 9 & 5 & $t$ & 9 & $t$ & 3 & 4 & $t$ & 13 & 4 & 3 & $i$ & 1 & 3 & 6 \\
\hline Ls & 2 & 1 & 16 & 13 & 24 & 52 & 24 & 104 & 40 & 106 & 18 & 26 & 22 & 4 & 19 & 27 & 38 & 71 & 32 & 27 & 27 \\
\hline $\mathrm{m}$ & 7 & 72 & 4 & 0 & 9 & 0 & 0 & 0 & 0 & 1 & 0 & 9 & $\Rightarrow$ & 51 & 4 & 1 & 0 & 3 & 1 & b & 2 \\
\hline De & 3 & 4 & 4 & 0 & 9 & 0 & 0 & 0 & 0 & 4 & 0 & 0 & 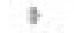 & 12 & 2 & 1 & 0 & 4 & 0 & b & 0 \\
\hline Dc & 4 & 0 & 4 & 0 & 9 & 0 & 0 & 0 & 0 & 7 & 0 & 0 & 3 & $t$ & 4 & 4 & 0 & 3 & 0 & b & 0 \\
\hline Dd & 5 & 6 & 3 & 9 & 9 & 0 & 0 & 0 & 0 & 1 & 0 & 9 & 3 & 208 & 87 & 45 & 1 & 3 & 2 & 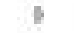 & 2 \\
\hline $\mathbf{D s}$ & 4 & 9 & 4 & 0 & 9 & 0 & P & 0 & $a$ & 3 & 9 & 0 & 3 & 5 & 4 & 1 & 0 & 1 & 0 & 2 & 1 \\
\hline $\mathrm{Bi}$ & 3 & 0 & 4 & 0 & 9 & 0 & 0 & 1 & $t$ & 3 & 0 & 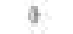 & 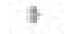 & 9 & 1 & 1 & 0 & 3 & 0 & b & 0 \\
\hline In & 43 & 0 & 10 & 1 & 9 & 11 & 13 & 7 & 57 & 3 & $t$ & $\theta$ & 3 & 0 & 2 & 13 & 6 & 1 & 3 & 2 & 3 \\
\hline $\mathrm{XQm}$ & 1 & D & 7 & 0 & 1 & 0 & 0 & 0 & 5 & 3 & 5 & 16 & 32 & 0 & 3 & , & 1 & 1 & 5 & I & 3 \\
\hline$X Q p$ & 1 & D & 5 & 0 & 0 & 0 & D & D & $t$ & 7 & 5 & 1 & 19 & $a$ & 2 & 1 & 0 & 1 & 1 & 1 & 1 \\
\hline $\mathrm{XQi}$ & 9 & D & 4 & 0 & 3 & 0 & D & D & a & 9 & $a$ & $a$ & 3 & 0 & 9 & 8 & a & 9 & $D$ & D & 0 \\
\hline$X Q \mathbf{r}$ & 0 & D & 4 & 0 & J & 0 & D & D & a & 9 & a & 0 & 7 & a & 9 & 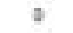 & a & 9 & D & D & D \\
\hline xKs & 4 & 0 & 3 & 0 & 9 & 0 & 0 & 1 & 0 & 4 & 4 & 9 & 10 & 9 & 3 & 1 & 9 & 3 & I & 5 & 0 \\
\hline XKK & 4 & 0 & 4 & 0 & ) & 0 & 0 & 0 & a & 4 & 9 & 9 & 3 & 9 & 3 & $\Rightarrow$ & 9 & 1 & 1 & b & 0 \\
\hline XIMf & 3 & 0 & 4 & 0 & 3 & 0 & 0 & D & a & 9 & a & $a$ & 7 & a & 9 & 3 & a & 9 & 0 & D & 0 \\
\hline $\mathrm{XCh}$ & 3 & D & 4 & 0 & 3 & 0 & D & 1 & a & 4 & a & 0 & 0 & a & 4 & 8 & a & 9 & D & b & D \\
\hline $\mathrm{XMc}$ & $a$ & D & 0 & 0 & a & 0 & D & D & a & 3 & $a$ & 0 & 0 & a & 9 & 0 & a & $a$ & $D$ & D & D \\
\hline $\mathrm{XOt}$ & 9 & D & $a$ & 0 & 3 & 0 & 1 & D & 10 & $a$ & a & $a$ & 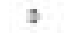 & a & 1 & 1 & a & $a$ & D & $\mathrm{D}$ & D \\
\hline XSc & a & D & 2 & 0 & 0 & 0 & 2 & D & 5 & $a$ & a & $a$ & 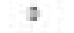 & a & $a$ & $a$ & a & $a$ & D & 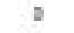 & D \\
\hline $\mathrm{XSf}$ & 3 & D & 4 & 0 & 3 & 0 & 1 & D & a & 9 & $a$ & 0 & 3 & a & 9 & 8 & a & 9 & 0 & D & D \\
\hline $\mathrm{XSm}$ & 9 & D & 4 & 0 & 3 & 0 & D & D & a & 4 & 0 & 0 & 0 & a & 3 & 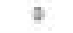 & a & 9 & D & D & D \\
\hline $\mathrm{XIm}$ & 10 & D & 2 & 0 & 0 & 2 & 77 & 2 & 25 & 9 & 0 & $a$ & 7 & o & 9 & 11 & a & 9 & 0 & 2 & D \\
\hline $\mathrm{XImb}$ & 11 & D & 9 & 0 & J & 0 & 2 & 1 & 7 & 2 & a & $a$ & 8 & a & 4 & 9 & a & 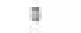 & D & 5 & D \\
\hline $\mathrm{XImr}$ & 1 & D & 0 & 0 & 0 & 0 & $B$ & D & 12 & 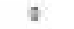 & a & 0 & 0 & 0 & 1 & $T$ & a & 9 & D & $\mathrm{D}$ & D \\
\hline$x I_{5}$ & 9 & D & 1 & 0 & 3 & 1 & 1 & 1 & 18 & 0 & a & a & 1 & a & 1 & 1 & a & 9 & D & D & D \\
\hline XIe & 3 & D & 7 & 0 & 0 & 0 & s & D & 19 & 9 & $t$ & 0 & 0 & 0 & 3 & 25 & $t$ & & $D$ & 1 & 1 \\
\hline XIc & 3 & D & 9 & 0 & J & 0 & 10 & D & 13 & 1 & a & 1 & 1 & d & 10 & 21 & a & 9 & 1 & 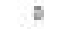 & D \\
\hline $\mathrm{XF} \bullet$ & 38 & D & 4 & 0 & a & 0 & 1 & D & 2 & $a$ & a & $a$ & 1 & a & 1 & 15 & a & 9 & D & 5 & D \\
\hline XIs & 2 & D & 3 & 0 & J & 0 & 2 & 3 & 13 & 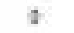 & a & $a$ & $a$ & a & $a$ & 2 & a & 1 & D & $D$ & D \\
\hline$x \mathbf{m}$ & 2 & D & 2 & 0 & 3 & 0 & D & D & a & $a$ & a & a & 4 & a & 4 & 2 & a & 3 & 0 & 5 & D \\
\hline$x D e$ & 3 & 0 & 4 & 0 & 0 & 0 & 6 & 0 & $t$ & 3 & a & a & t & a & 1 & 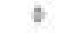 & a & $a$ & 0 & 5 & D \\
\hline$x \rightarrow c$ & 1 & 0 & 3 & 0 & 0 & 0 & 0 & 0 & 9 & 3 & 0 & 0 & 1 & 0 & 3 & 1 & 0 & 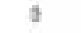 & 0 & 5 & 0 \\
\hline$x \boldsymbol{d}$ & 4 & D & 0 & 0 & J & 0 & D & 0 & a & 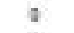 & a & 0 & 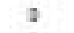 & a & 1 & 27 & a & 1 & D & 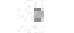 & D \\
\hline$x \mathbf{D}_{s}$ & 3 & D & 0 & 0 & 0 & D & D & D & a & 4 & a & $a$ & 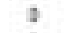 & a & a & 2 & a & 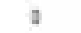 & D & $D$ & D \\
\hline XBi & 3 & D & 0 & 0 & 3 & 0 & D & D & a & 2 & a & a & 2 & a & 1 & $a$ & a & $a$ & 0 & 8 & D \\
\hline$x \mathrm{In}$ & 0 & 0 & 0 & 0 & $a$ & 0 & 6 & 0 & 3 & $a$ & 0 & $a$ & 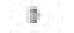 & a & 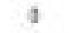 & 1 & a & 3 & 0 & 5 & 0 \\
\hline En & 2 & 0 & $y$ & a & 1 & 9 & 6 & 0 & 10 & 1 & 0 & 9 & $t$ & 0 & 1 & 2 & 9 & 1 & 0 & t & 0 \\
\hline Total & 406 & 236 & 424 & 408 & 390 & 447 & 418 & 411 & 430 & 416 & 405 & 407 & 411 & 405 & 422 & 407 & 403 & 414 & 414 & 418 & 410 \\
\hline
\end{tabular}


Appendix A (continued)

Medium fraction ( $\quad 0.5 \quad 0.25 \mathrm{~mm})$

\begin{tabular}{|c|c|c|c|c|c|c|c|c|c|c|c|c|c|c|c|c|c|c|c|}
\hline & CU-13 & CU-14 & CU-15 & CU-16 & CU-17 & CU-18 & CU-19 & CU-21 & CU-22 & CU-23 & CU.42 & MA-11 & MA-12 & MA-13 & MA-14 & MA-15 & MA-31 & MA-32 & MA-33 \\
\hline Qs & 3 & 149 & 222 & 262 & 187 & 121 & 264 & 255 & 209 & 163 & 13 & 78 & 222 & 241 & 229 & 254 & 46 & 65 & 64 \\
\hline Qp & 4 & 62 & 56 & 60 & 59 & 38 & 92 & 73 & 63 & 46 & 1 & 16 & 44 & 65 & 51 & 51 & 12 & 12 & 9 \\
\hline Qi & 3 & 0 & 9 & 2 & 0 & 0 & 1 & I & $\mathrm{P}$ & 2 & 3 & 0 & 2 & D & 1 & 3 & 2 & 4 & 0 \\
\hline Qr & + & 3 & 4 & 3 & 4 & 0 & 2 & 4 & 4 & $t$ & 1 & 9 & 2 & b & 0 & 3 & 9 & 0 & 1 \\
\hline Ks & 1 & 19 & 47 & 69 & 34 & 9 & 16 & 41 & 44 & 27 & 0 & 7 & 24 & 10 & 14 & 9 & 7 & 6 & 8 \\
\hline $\mathrm{Kr}$ & 9 & D & 1 & 3 & 1 & 1 & 3 & 4 & 5 & 0 & 0 & 0 & 1 & D & 1 & 5 & 0 & 0 & 1 \\
\hline$M f$ & $a$ & D & 1 & 0 & 2 & 1 & 3 & 3 & 3 & $t$ & 2 & a & 3 & 2 & 2 & 3 & 1 & 0 & 1 \\
\hline $\mathrm{Ch}$ & 9 & 1 & 3 & $t$ & $a$ & 2 & D & 0 & 8 & 0 & D & $a$ & 0 & D & D & 3 & $a$ & 0. & 0 \\
\hline Mc & 3 & b & 9 & 0 & 9 & 0 & b & 0 & $B$ & 0 & 0 & 0 & 0 & b & 0 & 4 & 0 & 0 & 0 \\
\hline $\mathrm{Ot}$ & 4 & 5 & 5 & 2 & 12 & 2 & 10 & 6 & 11 & 19 & 5 & 2 & 7 & 4 & 5 & J & 9 & 0 & 2 \\
\hline Sc & 4 & D & 3 & 9 & 2 & 0 & 1 & 4 & 1 & 3 & 1 & 0 & 0 & D & 0 & 3 & 9 & 0 & 0 \\
\hline$S f$ & $a$ & D & 0 & g & 0 & 0 & 3 & 0 & 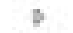 & $t$ & D & 0 & 3 & D & 1 & 1 & $a$ & 0 & 0 \\
\hline $\mathrm{Sm}$ & 3 & D & 3 & g & $a$ & 0 & 3 & 0 & $D$ & $a$ & D & $a$ & 0 & D & 1 & 3 & a & 0 & 0 \\
\hline $\mathrm{Lm}$ & $a$ & $T$ & 3 & $t$ & 2 & 15 & D & $t$ & 13 & 27 & 31 & 78 & 42 & 2 & 13 & 3 & 74 & 47 & 33 \\
\hline $\mathrm{Lmb}$ & $a$ & 1 & 9 & 2 & 3 & 3 & $D$ & 2 & 13 & 29 & 30 & 3 & 4 & D & I & 3 & $\mathbf{3}$ & 13 & 8 \\
\hline $\mathrm{Lmr}$ & 3 & D & 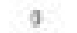 & 0 & 0 & 0 & D & 3 & 9 & 11 & 37 & 25 & 6 & 1 & 5 & 3 & 10 & 33 & 2 \\
\hline $\mathrm{L}_{\mathbf{k}}$ & 0 & D & 3 & 0 & a & 0 & D & 1 & 8 & 18 & 25 & a & 5 & D & 1 & 3 & 5 & 2 & 9 \\
\hline Le & 4 & 7 & 3 & 2 & 5 & 12 & D & 4 & 3 & 26 & 78 & 44 & 25 & 4 & 13 & 4 & 57 & 60 & 26 \\
\hline Lc & 1 & 1 & 2 & $t$ & 4 & 4 & $D$ & 2 & 13 & 10 & 81 & 2 & 1 & 10 & 5 & 3 & 61 & 76 & 34 \\
\hline $\mathrm{F} \bullet$ & $a$ & 4 & 0 & a & $a$ & 1 & D & $t$ & 4 & 11 & 4 & 2 & 5 & I & 2 & 3 & 12 & 14 & 3 \\
\hline Ls & it & 1 & 3 & 0 & 3 & 5 & D & 3 & 2 & 7 & 11 & $t$ & 2 & D & 1 & $a$ & 4 & 6 & 3 \\
\hline $\mathbf{D m}$ & 0 & b & 3 & 0 & a & 0 & D & 3 & $D$ & 0 & 0 & 9 & 0 & 12 & 12 & 6 & $s$ & 17 & 20 \\
\hline De & 3 & 3 & 3 & $t$ & 3 & 4 & D & $t$ & 4 & $a$ & 10 & $t$ & 5 & 17 & 10 & 24 & 33 & 35 & 23 \\
\hline $\mathbf{D c}_{\mathrm{c}}$ & 1 & 1 & 9 & 0 & $t$ & 0 & D & $t$ & 3 & 0 & 1 & 5 & 2 & 23 & 27 & 25 & 24 & D & 11 \\
\hline Dd & 3 & 1 & 3 & a & 2 & 8 & 2 & 0 & $D$ & $a$ & 64 & 2 & 1 & D & 5 & $a$ & 46 & 16 & 0 \\
\hline $\mathbf{D}_{\mathrm{s}}$ & 3 & D & 2 & a & 2 & 0 & D & 0 & D & $a$ & 0 & a & D & D & D & $a$ & $a$ & 0 & 0 \\
\hline $\mathrm{Bi} \bullet$ & 15 & 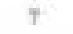 & $a$ & 2 & 3 & 11 & b & 0 & b & $t$ & 0 & 0 & 0 & b & D & 3 & 0 & 0 & 0 \\
\hline In & 475 & 59 & 2 & 4 & 20 & 99 & 4 & 0 & 2 & 3 & $t$ & 24 & 5 & 5 & 2 & 3 & $t$ & 5 & 69 \\
\hline $\mathrm{XQm}$ & 43 & 63 & 23 & 0 & 37 & 48 & 2 & 1 & 3 & t & 0 & 9 & $t$ & 8 & 1 & 3 & 0 & 0 & 37 \\
\hline $\mathrm{XQp}$ & 14 & 31 & 3 & 0 & 11 & 17 & D & $t$ & 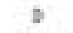 & a & D & $t$ & 0 & D & D & 1 & $a$ & o & 16 \\
\hline$X Q i$ & $a$ & D & 0 & 0 & 0 & 0 & b & 0 & b & $a$ & 0 & a & 0 & b & b & $a$ & $a$ & 0 & 0 \\
\hline$X Q r$ & 3 & D & $a$ & 0 & $\mathrm{t}$ & 3 & b & 0 & b & 0 & 0 & a & 0 & b & D & 3 & a & 0 & 0 \\
\hline XKs & 6 & 6 & 4 & 0 & 5 & 2 & 1 & 0 & 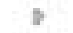 & $t$ & 0 & 0 & $\mathrm{t}$ & 8 & 0 & t & 0 & 0 & 0 \\
\hline $2 \mathrm{KKr}$ & 3 & 0 & 9 & 0 & 1 & & 6 & 0 & $\$$ & 9 & 0 & 0 & 0 & 8 & 0 & 7 & 0 & 0 & 0 \\
\hline $\mathrm{xMf}$ & 3 & 0 & 9 & 0 & 0 & 0 & 1 & 0 & 5 & 0 & 0 & 0 & 0 & 18 & 0 & 7 & 0 & 0 & 0 \\
\hline $\mathrm{XCh}$ & 3 & $\theta$ & 9 & 0 & 9 & 0 & 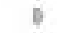 & 0 & 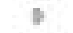 & 9 & 0 & 0 & 0 & p & 0 & 0 & 0 & 0 & 0 \\
\hline $\mathrm{X} \mathrm{Mc}$ & 3 & 6 & 9 & 0 & 0 & 0 & 1 & 0 & $D$ & 0 & 0 & 0 & 0 & 6 & 0 & 3 & 0 & 0 & 0 \\
\hline $\mathrm{xOt}$ & 3 & 0 & 9 & 0 & $\mathrm{t}$ & 4 & 2 & 0 & $D$ & 0 & 9 & 0 & 0 & ly & 1 & 7 & 9 & 0 & 0 \\
\hline XSc & 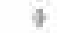 & 0 & 9 & 0 & 9 & 0 & 8 & 0 & 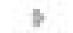 & 0 & 0 & 0 & 0 & 1 & 0 & 3 & 0 & 0 & 0 \\
\hline $\mathrm{XSf}$ & 3 & 1 & 9 & 0 & 1 & 0 & 1 & 0 & 5 & 0 & 0 & 0 & 0 & 1 & 0 & 3 & 0 & 0 & 0 \\
\hline $\mathrm{XSm}$ & 3 & 0 & 9 & 0 & 9 & 0 & 8 & 0 & 8 & 0 & 0 & 0 & 0 & 8 & 0 & 3 & 9 & 0 & 0 \\
\hline $\mathrm{xI} \mathrm{m}$ & 4 & 3 & 9 & 0 & 2 & 3 & 8 & 0 & 8 & 1 & 0 & 0 & 0 & 8 & 0 & 3 & 9 & 0 & 1 \\
\hline $\mathrm{x} I \mathrm{mb}$ & 3 & 0 & 3 & 0 & 0 & 1 & 0 & 0 & 7 & 0 & 0 & a & 0 & 0 & 0 & 0 & 0 & 0 & 0 \\
\hline $\mathrm{XI} \mathrm{mr}$ & 1 & 0 & 9 & 0 & 0 & 1 & 1 & 0 & 8 & 0 & 0 & 0 & 0 & e & 0 & 3 & 0 & 0 & 0 \\
\hline$x I_{\xi}$ & 3 & 1 & 9 & 0 & 9 & 0 & 8 & 0 & 1 & 0 & 0 & 0 & 0 & b & 0 & 0 & 0 & 0 & 0 \\
\hline$x+e$ & 3 & 8 & 3 & 9 & 3 & 19 & 8 & 0 & 7 & 2 & 0 & 0 & 0 & 8 & 0 & 3 & 0 & 0 & 1 \\
\hline $\mathrm{XIc}$ & 1 & 0 & 3 & 0 & 3 & 7 & 8 & 0 & 7 & 3 & 0 & 9 & 0 & 8 & 0 & 3 & 0 & 0 & 2 \\
\hline $\mathrm{XF} \bullet$ & 2 & 1 & 3 & 0 & 0 & 0 & D & 0 & 8 & 0 & 0 & 0 & 0 & D & 0 & 9 & 0 & 0 & 0 \\
\hline xIs & 4 & D & 3 & 0 & 0 & D & $D$ & 0 & $D$ & $a$ & 0 & $a$ & D & $D$ & 0 & $a$ & $a$ & D & $a$ \\
\hline $\mathrm{x} \mathbf{m}$ & $a$ & D & $a$ & a & a & 0 & $D$ & 0 & $D$ & a & D & $a$ & 0 & $D$ & 0 & $a$ & $a$ & D & 0 \\
\hline xDe & 1 & 2 & 9 & 0 & 1 & 2 & 8 & 0 & 7 & 0 & 0 & 9 & 0 & 8 & 0 & 1 & 9 & 0 & 5 \\
\hline$x \mathbf{D c}$ & 1 & 2 & 3 & 0 & a & 6 & 8 & 0 & 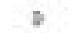 & $t$ & 0 & $a$ & 0 & D & 0 & 1 & 0 & 0 & 12 \\
\hline$x \mathbf{D}$ & 3 & 1 & 3 & 0 & 0 & 2 & D & 0 & 8 & 0 & 0 & $a$ & 0 & D & 0 & 3 & 0 & 0 & 0 \\
\hline$x \mathbb{D}_{s}$ & 2 & D & 3 & 0 & $\mathrm{t}$ & 0 & $D$ & 0 & $D$ & $a$ & D & $a$ & D & $D$ & D & $a$ & 0 & 0 & 0 \\
\hline $\mathrm{xBi}$ & 2 & D & 3 & 0 & a & D & $D$ & 0 & $D$ & 0 & D & 0 & D & $D$ & D & 3 & 0 & 0 & 0 \\
\hline XIn & 27 & 1 & 3 & 0 & $\mathrm{t}$ & 2 & D & 0 & $D$ & $a$ & D & a & 0 & D & 1 & 3 & 0 & 0 & 0 \\
\hline En & 12 & 5 & 1 & 0 & 3 & 20 & D & 0 & 8 & 0 & 0 & 0 & 0 & $D$ & 0 & 3 & 0 & 0 & 10 \\
\hline Total & 626 & 460 & 415 & 415 & 426 & 476 & 400 & 415 & 415 & 415 & 410 & 300 & 415 & 398 & 412 & 400 & 412 & 411 & 400 \\
\hline
\end{tabular}




\begin{tabular}{|c|c|c|c|c|c|c|c|c|c|c|c|c|c|c|c|c|c|c|c|c|}
\hline & MA-34 & MA-35 & MA.42 & MA.43 & MA-44 & MA-45 & MA.46S & $\mathrm{CN}-21$ & $\mathrm{CN}-21 \mathrm{~S}$ & FU-11 & FU-12 & FU-31 & FU.41 & FU.43 & FU-45 & FU.46 & FU.410 & FU-411 & FU.411S & TR-31 \\
\hline Qs & 11 & 10 & 134 & 171 & 46 & 5 & 3 & 21 & 160 & 273 & 10 & 96 & 82 & 32 & 50 & 60 & 198 & 230 & 246 & 33 \\
\hline Qp & 2 & 2 & 38 & 69 & 10 & 2 & 0 & 5 & 66 & 67 & 2 & 30 & 31 & 3 & 28 & 14 & 45 & 73 & 102 & 14 \\
\hline Qi & 4 & 0 & 0 & 0 & 4 & l & 0 & 9 & 0 & 3 & 3 & 9 & $\theta$ & 9 & 0 & 6 & 9 & 3 & 3 & 0 \\
\hline Qr & 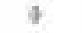 & 0 & 2 & 4 & 9 & $\geqslant$ & 0 & 9 & 1 & 6 & 1 & 0 & 2 & 1 & 1 & 0 & 9 & 3 & 1 & 0 \\
\hline $\mathrm{Ks}$ & 3 & 0 & 13 & 12 & 1 & J & 0 & 4 & 25 & 40 & 5 & 4 & 7 & 4 & 0 & 3 & 21 & 4 & 32 & $T$ \\
\hline $\mathrm{Kr}$ & 3 & 0 & 9 & $t$ & 0 & $\geqslant$ & 0 & 0 & 9 & 3 & 1 & 0 & 2 & 0 & 0 & 0 & 0 & 3 & 7 & D \\
\hline $\mathrm{Mf}$ & 2 & 0 & 25 & 4 & 3 & 3 & 3 & 7 & 9 & 2 & 7 & 9 & & 0 & 0 & 0 & 2 & $\theta$ & 5 & $D$ \\
\hline $\mathrm{Ch}$ & 3 & D & 1 & 2 & 0 & 2 & 0 & 0 & a & 1 & 8 & 0 & $a$ & 0 & D & 0 & 1 & 2 & 0 & D \\
\hline Mo & 3 & 0 & 0 & 0 & 9 & $\geqslant$ & 0 & 9 & 9 & $D$ & 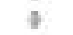 & 0 & 9 & 0 & 0 & 0 & 0 & 4 & 5 & 0 \\
\hline $\mathrm{Ot}$ & 0 & 2 & 39 & 3 & 0 & $\geqslant$ & 1 & 0 & 4 & 0 & 5 & 2 & 3 & 5 & 4 & 18 & 2 & 3 & 2 & 2 \\
\hline Sc & 3 & 1 & 0 & 9 & $t$ & 7 & 0 & 0 & $t$ & D & 9 & 9 & 1 & 9 & 1 & 0 & 9 & 3 & 9 & 1 \\
\hline$S f$ & 0 & $D$ & 0 & 0 & 9 & 0 & 0 & 0 & 2 & D & 7 & 0 & a & 0 & 1 & 0 & 0 & 0 & 7 & 0 \\
\hline $\mathrm{Sm}$ & 9 & D & 0 & 0 & a & 2 & 0 & 0 & & D & 8 & 0 & $a$ & 0 & 1 & 0 & 0 & 0 & 1 & 0 \\
\hline $\mathrm{Lm}$ & 21 & 69 & 15 & 2 & 56 & 25 & 12 & 7 & 15 & D & 1 & 13 & 18 & 3 & 21 & 3 & 14 & 1 & 2 & 18 \\
\hline $\mathrm{Lmb}$ & $\pi$ & 2 & $b$ & $t$ & t & 143 & 175 & 0 & 2 & D & 7 & 14 & 5 & 13 & 4 & 1 & 1 & $a$ & 7 & D \\
\hline $\mathrm{Lmr}$ & 7 & 19 & 5 & 0 & 43 & 3 & 1 & 9 & 0 & 1 & 3 & 5 & $a$ & 1 & 4 & 0 & 5 & $\theta$ & 3 & 14 \\
\hline $\mathrm{L}_{\mathbf{k}}$ & 0 & D & 1 & $t$ & t & 3 & 0 & 0 & $t$ & D & 8 & 3 & $a$ & 4 & 1 & $t$ & 1 & 3 & 9 & 1 \\
\hline Le & 34 & 30 & 12 & 5 & 82 & 9 & 4 & $a$ & 13 & $T$ & 16 & 21 & 17 & 11 & 17 & 18 & 5 & $a$ & 8 & 39 \\
\hline Lc & 31 & 23 & $s$ & 4 & 42 & 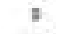 & A & 2 & 14 & 4 & 47 & $\nabla$ & 1 & 7 & $B$ & 27 & 11 & 2 & 8 & 51 \\
\hline $\mathrm{F} \bullet$ & 9 & 4 & 7 & 1 & $a$ & 15 & 11 & 0 & 4 & D & 2 & 0 & 3 & 15 & 5 & 0 & $b$ & 1 & 5 & 11 \\
\hline Ls & 1 & D & 1 & $a$ & 3 & $=$ & 0 & 0 & 2 & b & 8 & 4 & 6 & 1 & 16 & 0 & 1 & 1 & 8 & 2 \\
\hline $\mathbf{D m}$ & $T$ & 30 & 1 & 13 & 33 & 5 & $\$$ & 0 & 2 & b & 29 & 9 & 6 & 5 & 9 & 14 & 3 & 6 & 1 & 3 \\
\hline De & 9 & 76 & 5 & 25 & 31 & 158 & 143 & $a$ & 3 & 1 & 57 & 12 & 16 & s & 26 & 52 & 20 & 4 & 2 & $\mathrm{~s}$ \\
\hline $\mathbf{D c}$ & 3 & 41 & 24 & 52 & 10 & 5 & 19 & 4 & 4 & 2 & 183 & 19 & 18 & 24 & $T$ & 168 & 28 & 35 & 1 & 9 \\
\hline Dd & 3 & 27 & 0 & 2 & 13 & 35 & 24 & 3 & 4 & D & 39 & 3 & $a$ & 0 & 5 & 3 & 0 & 1 & 2 & 1 \\
\hline $\mathbf{D}_{\mathrm{s}}$ & $a$ & 3 & 0 & 0 & $a$ & 3 & 0 & 0 & a & b & 3 & 0 & 0 & 0 & D & 0 & 0 & 3 & t & 0 \\
\hline Bi॰ & 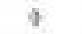 & 0 & 0 & 0 & 0 & 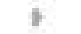 & 0 & 0 & 0 & 0 & 1 & 2 & 11 & 3 & 9 & 1 & 0 & 1 & 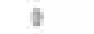 & 0 \\
\hline In & 210 & 12 & 20 & 5 & $?$ & 2 & 4 & 353 & 29 & $b$ & 3 & 8 & 39 & 101 & 48 & 20 & 36 & 34 & $t$ & 284 \\
\hline $\mathrm{XQm}$ & 2 & 1 & 15 & 1 & 0 & 1 & 0 & 5 & 27 & 0 & 1 & 51 & 60 & 14 & 41 & 0 & 9 & 1 & 1 & 0 \\
\hline$X Q p$ & a & D & 3 & a & 0 & 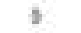 & 0 & 0 & 9 & b & t & 26 & 18 & 7 & 14 & $t$ & 0 & 4 & t & 0 \\
\hline $\mathrm{XQi}$ & 0 & 1 & 0 & 0 & 0 & $b$ & 0 & 0 & 0 & 0 & b & 0 & $a$ & 0 & 0 & 0 & 0 & 4 & b & 0 \\
\hline$X Q r$ & 4 & 0 & 0 & 9 & 0 & 1 & 0 & 0 & 0 & 0 & 1 & 0 & 0 & 0 & 1 & 0 & 0 & 4 & 1 & 0 \\
\hline xKs & 4 & 0 & 0 & 9 & 0 & 1 & 0 & 2 & 2 & 0 & 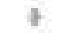 & 4 & 9 & 4 & 2 & 0 & 0 & 4 & 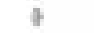 & 0 \\
\hline xKr & 9 & 0 & 0 & 9 & 0 & $b$ & $\theta$ & 9 & 0 & 0 & 7 & 0 & $\theta$ & 0 & 0 & 0 & 0 & 1 & 7 & 0 \\
\hline XMf & 9 & $D$ & 1 & 0 & 9 & 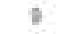 & 0 & 9 & 0 & D & 3 & 0 & 3 & 1 & 0 & 0 & 0 & 3 & 7 & 0 \\
\hline $\mathrm{xCh}$ & 9 & D & 0 & 9 & 0 & $\geqslant$ & 9 & 9 & 0 & D & 3 & 0 & $a$ & 0 & $D$ & 0 & 0 & 9 & 9 & D \\
\hline $\mathrm{XMC}$ & 9 & 0 & 0 & 9 & 0 & $b$ & 0 & 9 & 0 & 0 & $t$ & 0 & 0 & 0 & 0 & 0 & 0 & 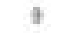 & 4 & $\theta$ \\
\hline xOt & 4 & 0 & 2 & 9 & 0 & 1 & 0 & 9 & 0 & 0 & 7 & 2 & 5 & 4 & 3 & 0 & 0 & 9 & 3 & 0 \\
\hline$X S c$ & 3 & 0 & 0 & 0 & 0 & 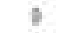 & 0 & 0 & 0 & 0 & 4 & 0 & 1 & 0 & 0 & 0 & 9 & 3 & 3 & 0 \\
\hline $\mathrm{XSf}$ & 3 & $D$ & 9 & 0 & 9 & $\Rightarrow$ & 0 & 0 & 0 & D & 3 & 1 & 0 & 0 & 0 & 0 & 9 & 3 & 9 & 0 \\
\hline $\mathrm{XSm}$ & 9 & $D$ & 0 & 0 & 0 & 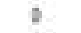 & 0 & 0 & 0 & $D$ & 2 & 0 & $a$ & 9 & D & 0 & 0 & 3 & 9 & D \\
\hline $\mathrm{XIm}$ & 3 & D & 0 & $a$ & $a$ & 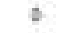 & 0 & 9 & $a$ & $D$ & 9 & 4 & 3 & 24 & 1 & 0 & a & 3 & 3 & 1 \\
\hline $\mathrm{XImb}$ & 7 & 0 & 0 & 9 & 9 & 1 & 0 & 0 & 0 & 0 & 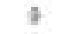 & 8 & 2 & 4 & 5 & 0 & 0 & 3 & 3 & 0 \\
\hline $\mathrm{XImr}$ & 3 & 0 & 1 & 0 & 0 & 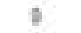 & 0 & 9 & 0 & $D$ & 3 & 0 & 1 & 0 & 0 & 0 & 9 & 3 & 3 & D \\
\hline$x I_{5}$ & 9 & D & 9 & 0 & 0 & $\Rightarrow$ & 0 & 0 & 0 & D & 3 & 5 & 9 & 3 & 1 & 0 & 0 & 3 & 3 & 9 \\
\hline XIe & 5 & 1 & 1 & 0 & $a$ & $D$ & 0 & 0 & $t$ & $D$ & 8 & $z$ & 10 & 53 & 8 & 0 & 0 & 3 & 9 & 2 \\
\hline XIc & 24 & 2 & 0 & a & 2 & $=$ & 0 & a & 4 & $D$ & 8 & s & 7 & 20 & 0 & 3 & a & 2 & 0 & 3 \\
\hline $\mathrm{XF} \bullet$ & 1 & $D$ & 1 & $a$ & $a$ & $=$ & 0 & a & a & D & 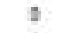 & 5 & 5 & 17 & 1 & 0 & a & $a$ & 3 & D \\
\hline XIs & $a$ & D & 0 & $a$ & a & 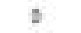 & 0 & a & $a$ & D & 2 & 0 & $a$ & $a$ & D & 0 & $a$ & 3 & 2 & D \\
\hline$x \mathbf{m}$ & 9 & 4 & 0 & 0 & 0 & $D$ & 0 & 0 & 0 & D & 2 & 0 & 9 & 0 & 8 & 0 & 0 & 3 & 9 & $D$ \\
\hline$x \mathrm{xe}$ & 2 & 21 & 0 & 0 & $a$ & 8 & 0 & 0 & a & D & 8 & 9 & 6 & 5 & 5 & 1 & a & 0 & 0 & D \\
\hline$x \mathbf{C}$ & 9 & 23 & 3 & a & a & $D$ & 0 & $a$ & $t$ & D & 7 & 5 & 5 & 19 & 1 & 2 & $a$ & 3 & 3 & $D$ \\
\hline$x \mathbf{d}$ & 0 & 2 & 0 & 0 & $a$ & $z$ & 0 & $a$ & a & D & 2 & 3 & $a$ & 1 & 1 & $a$ & a & 3 & 8 & $D$ \\
\hline$x \mathbf{s}$ & 9 & 2 & 0 & $a$ & $a$ & $\geqslant$ & 0 & $a$ & a & D & 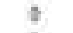 & 0 & a & 9 & D & 0 & 9 & 3 & 8 & D \\
\hline XBi & $a$ & D & 9 & $a$ & $a$ & \pm & 0 & 2 & $a$ & D & 2 & 0 & $a$ & $a$ & $D$ & 0 & 0 & 2 & 5 & D \\
\hline $2 \mathrm{In}$ & 18 & $y$ & 13 & $a$ & 0 & t & 0 & $a$ & a & b & 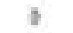 & 1 & 2 & 9 & 2 & 0 & 0 & 4 & 5 & 5 \\
\hline En & 5 & 3 & 4 & $a$ & a & $D$ & 0 & 2 & 5 & D & 8 & 14 & 6 & 31 & $T$ & 1 & a & 0 & 8 & D \\
\hline Total & 400 & 412 & 400 & 400 & 400 & 413 & 413 & 400 & 399 & 410 & 412 & 414 & 409 & 465 & 376 & 421 & 400 & 400 & 401 & 501 \\
\hline
\end{tabular}




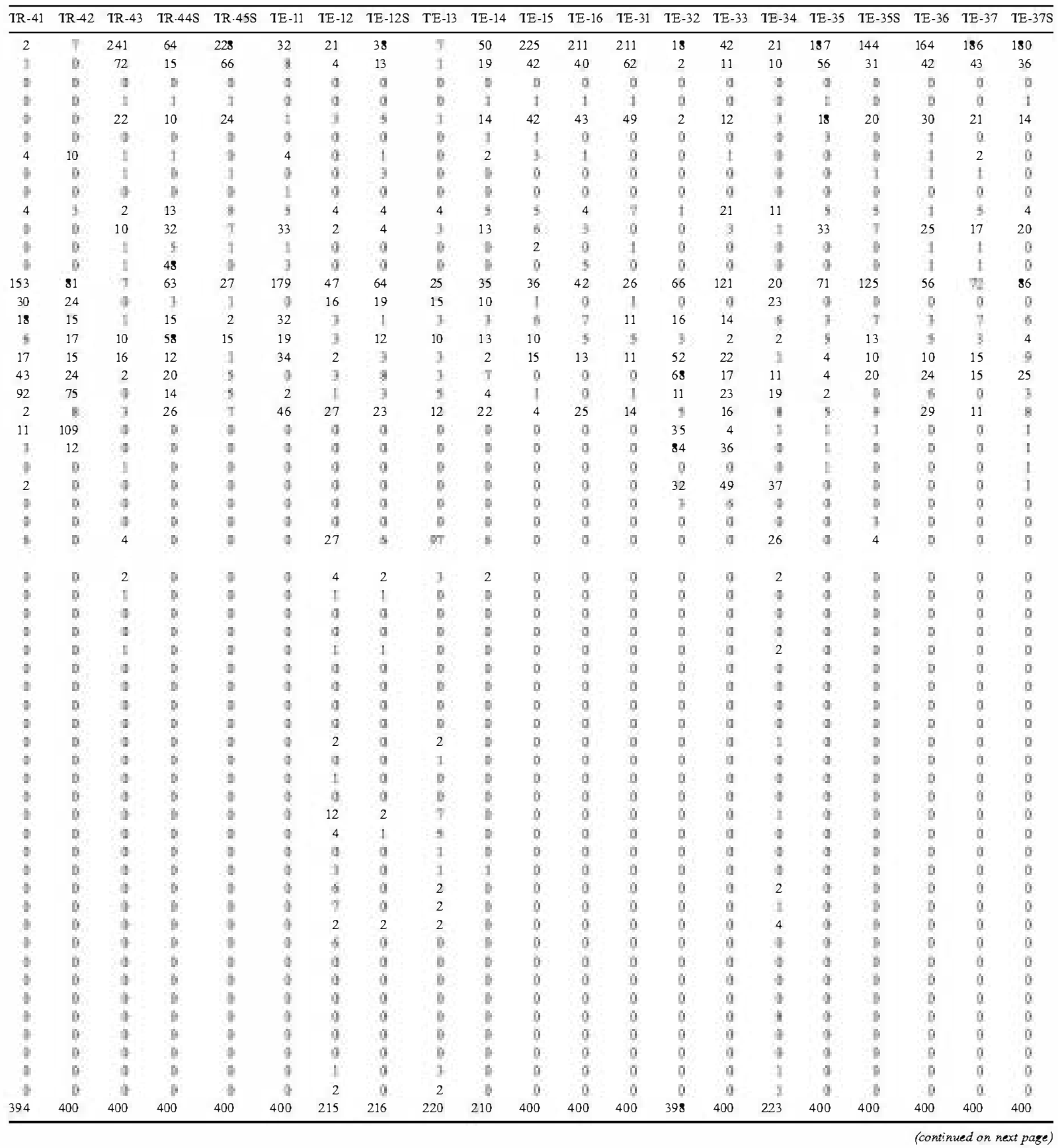




\begin{tabular}{|c|c|c|c|c|c|c|c|c|c|c|c|c|c|c|c|c|c|c|c|c|}
\hline & CU-13 & CU-14 & CU-15 & CU-16 & $\mathrm{CU}-17$ & CU-18 & CU-19 & CU-21 & CU-22 & CU-23 & CU-42 & MA-11 & $\mathrm{MA}-12$ & MA-13 & MA-14 & MA-15 & MA-31 & MA-32 & MA-33 & $\mathrm{MA}-34$ \\
\hline Qs & 16 & & 211 & 268 & 216 & 117 & 291 & 241 & 211 & 116 & 25 & 125 & 189 & 200 & 213 & 188 & 27 & 44 & 52 & 12 \\
\hline $\mathrm{Qp}$ & 5 & & 48 & 38 & 34 & 26 & 74 & 48 & 31 & 23 & 2 & 15 & 26 & 34 & 24 & 32 & 4 & 5 & 7 & I \\
\hline$Q^{i}$ & b & & 0 & 1 & 1 & 0 & 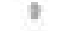 & 0 & 0 & 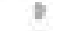 & 0 & 0 & D & 0 & 1 & 3 & 0 & b & 0 & 1 \\
\hline Ks & 3 & & 85 & 89 & 51 & 14 & 19 & 47 & 54 & 27 & D & , & 39 & 32 & 24 & 23 & 4 & 11 & 15 & 2 \\
\hline $\mathrm{Kr}$ & b & & a & 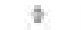 & t & $t$ & $t$ & 1 & a & 3 & D & 0 & 1 & a & b & $t$ & 0 & b & 0 & 0 \\
\hline Mf & b) & & 5 & 1 & 4 & 6 & 17 & 41 & 12 & $t$ & 14 & 3 & 5 & 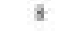 & 5 & 5 & 0 & $b$ & $\mathrm{t}$ & 2 \\
\hline $\mathrm{Ch}$ & b & & $t$ & 1 & 0 & $t$ & 2 & $\theta$ & 0 & 1 & 5 & 0 & D & t & i & 0 & 9 & 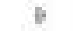 & 0 & 0 \\
\hline Sc & b & & 4 & 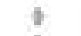 & 0 & a & 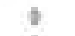 & 0 & a & 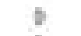 & 0 & 0 & to & $a$ & b & a & 0 & b & 0 & 0 \\
\hline $\mathrm{Sf}$ & B & & 9 & 1 & 9 & 0 & 3 & 0 & 9 & 1 & 0 & 0 & e & 9 & 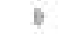 & 0 & 0 & b & 0 & 0 \\
\hline $\mathrm{Sm}$ & D & & 0 & $t$ & 0 & 0 & 7 & 0 & 0 & 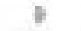 & 0 & 0 & D & 9 & 18 & $\theta$ & 0 & D & 9 & 0 \\
\hline Lm & 1 & & 2 & 3 & 7 & 14 & 7 & 5 & 45 & 129 & 103 & 94 & 50 & 22 & 24 & 20 & 41 & 56 & 18 & 8 \\
\hline Lmb & D & & 9 & 9 & 9 & I & 1 & 0 & 1 & 4 & 8 & 16 & 1 & 9 & D & 9 & 20 & 17 & 9 & 3 \\
\hline Lmr & 0 & & 9 & 9 & 0 & 0 & 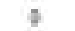 & 0 & 9 & 5 & 6 & 11 & D & 9 & 8 & 0 & 3 & 4 & $g$ & 1 \\
\hline $\mathrm{L}_{\mathbf{g}}$ & 0 & & a & $\theta$ & 0 & I & $\theta$ & D & 9 & 3 & D & 3 & 1 & 9 & D & $t$ & 0 & 3 & $g$ & 0 \\
\hline De & D & & 3 & 1 & 5. & 3 & 4 & 2 & I & 1 & 2 & 2 & $T$ & I & 16 & 14 & 10 & s & 12 & 2 \\
\hline $\mathbf{D}_{\mathrm{c}}$ & 1 & & 20 & 12 & 30 & 49 & 2 & 11 & 21 & 5 & 28 & 14 & 15 & 53 & 66 & 61 & 143 & 87 & 55 & 48 \\
\hline Di & $D$ & & $t$ & 2 & 7 & t & 9 & 0 & t & 7 & 10 & 2 & 3 & 3 & 4 & 7 & 28 & 19 & 7 & 0 \\
\hline $\mathbf{D} \mathrm{s}$ & D & & $\mathrm{t}$ & 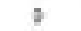 & 2 & 2 & 9 & 2 & 1 & $D$ & D & 0 & 1 & 9 & $D$ & 0 & 1 & $D$ & t & 0 \\
\hline $\mathrm{Bi} \bullet$ & 2 & & a & 2 & 1 & a & 2 & D & a & 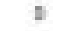 & D & 0 & $D$ & a & $D$ & a & 0 & $D$ & 0 & 0 \\
\hline In & 416 & & 16 & 12 & 47 & 149 & a & 1 & 3 & 17 & 12 & 122 & 48 & 39 & 26 & 20 & 10 & 16 & 207 & 352 \\
\hline $\mathrm{XQm}$ & 3 & & , & 3 & 3 & 20 & a & D & a & 1 & D & 1 & D & a & D & a & 0 & $D$ & 17 & 0 \\
\hline $\mathrm{XQp}$ & D & & t & 2 & 3 & s & 2 & D & 0 & 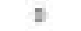 & D & 0 & D & a & 1 & $t$ & D & $D$ & a & D \\
\hline $\mathrm{XQi}$ & D & & a & 0 & $a$ & a & a & D & a & $D$ & D & a & D & d & D & a & D & $D$ & a & D \\
\hline $\mathrm{XQr}$ & D & & a & 2 & 0 & a & 0 & D & a & 2 & D & 0 & $D$ & a & $D$ & a & 0 & $D$ & a & 0 \\
\hline XKs & 2 & & 2 & 0 & 0 & 3 & 8 & D & a & 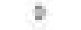 & D & a & 1 & a & D & a & 0 & $D$ & t & D \\
\hline 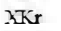 & D & & a & $\Rightarrow$ & 0 & a & b & D & a & 8 & 0 & 0 & D & $a$ & b & a & 0 & D & a & D \\
\hline $\mathrm{xI}$ & b & & 0 & $y$ & 0 & 0 & 1 & 0 & a & $t$ & 0 & 0 & 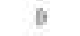 & $\theta$ & $b$ & 0 & 0 & b & 0 & 0 \\
\hline$x z e$ & $\theta$ & & 0 & 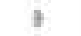 & 0 & 2 & 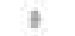 & $\theta$ & a & t & 0 & 0 & 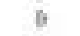 & 9 & $\theta$ & 0 & 0 & $b$ & 0 & 2 \\
\hline XIc & 1 & & 0 & 1 & 0 & 3 & 1 & 0 & 0 & 1 & 0 & 0 & 0 & 9 & $B$ & 9 & 0 & b & 1 & 3 \\
\hline $\mathrm{XF} \bullet$ & D & & 9 & 7 & 0 & 1 & 7 & D & a & 1 & 0 & 0 & 0 & 0 & $D$ & 0 & 9 & D & 0 & 2 \\
\hline XIs & D & & 0 & 8 & 0 & a & $\Rightarrow$ & D & a & 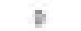 & 0 & 0 & D & a & $D$ & 0 & 0 & D & a & g \\
\hline$x \rightarrow \mathrm{m}$ & $D$ & & a & 8 & 0 & $a$ & 8 & D & a & 8 & 0 & 0 & D & 0 & D & a & 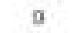 & $D$ & a & a \\
\hline$x \boldsymbol{~} \mathrm{x}$ & D & & 0 & 1 & 9 & 1 & $t$ & $\theta$ & 0 & $\theta$ & 0 & 0 & D & 9 & D & 0 & 0 & D & 3 & 0 \\
\hline$x \nabla c$ & 1 & & 1 & 1 & 0 & 16 & 8 & 0 & a & $B$ & 0 & 1 & 1 & 2 & 0 & 0 & 0 & D & 14 & 25 \\
\hline$x \mathbf{d}$ & D & & $a$ & 9 & 0 & $a$ & 8 & D & a & D & 0 & 0 & D & 9 & D & 0 & 9 & D & $t$ & 0 \\
\hline$x \mathbf{D}_{\mathrm{s}}$ & $D$ & & $a$ & 8 & a & $a$ & 8 & D & $a$ & 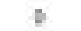 & D & a & D & $a$ & D & 0 & 0 & $D$ & $a$ & 0 \\
\hline $\mathrm{xBi}$ & $D$ & & a & 0 & a & $a$ & 8 & D & a & $D$ & $D$ & a & D & 0 & D & 0 & 0 & D & $a$ & 0 \\
\hline 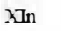 & 4 & & a & 3 & a & 1 & 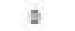 & 0 & a & $D$ & 0 & 5 & 3 & a & D & t & D & D & a & s \\
\hline En & D & & a & 0 & a & 3 & 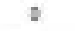 & D & a & 8 & D & a & D & 0 & D & a & 0 & D & t & 3 \\
\hline Total & 456 & & 422 & 428 & 446 & 461 & 428 & 436 & 440 & 442 & 439 & 504 & 429 & 435 & 446 & 422 & 411 & 417 & 451 & 519 \\
\hline
\end{tabular}

${ }^{\circ}$ Non-available sand from this fraction. 


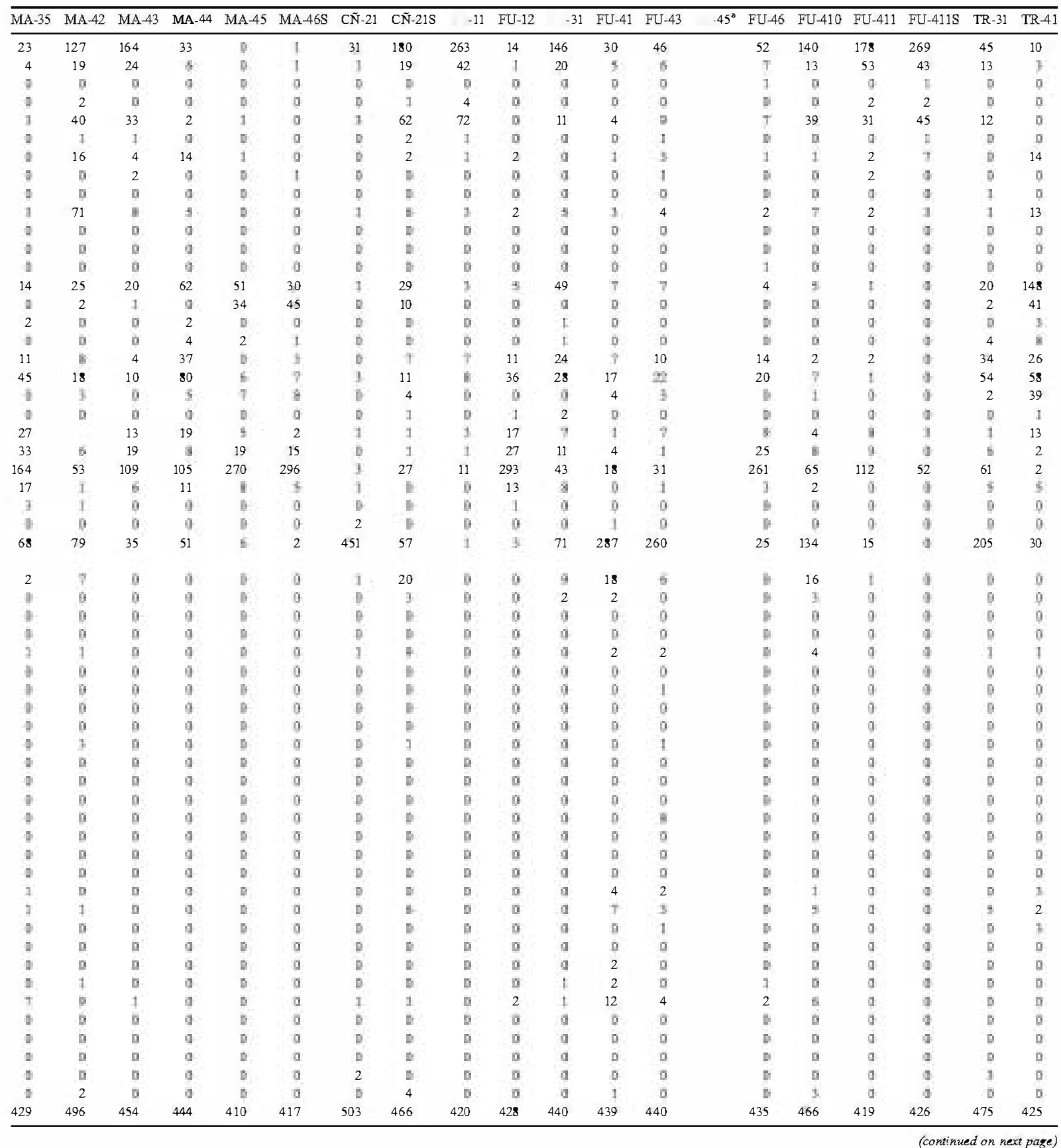




\begin{tabular}{|c|c|c|c|c|c|c|c|c|c|c|c|c|c|c|c|c|c|c|c|c|}
\hline & TR.42 & TR.43 & TR-44S & TR-45S & TE-11 & TE-12 & TE-12S & TE-13 & TE-14 & TE-15 & TE-16 & TE-31 & TE-32 & TE-33 & TE-34 & TE-35 & TE-35S & TE-36 & TE-37 & TE-37S \\
\hline Qs & 27 & 228 & 162 & 239 & 93 & 55 & 116 & 40 & 128 & 203 & 185 & 216 & 37 & 81 & 55 & 214 & 163 & 186 & 212 & 194 \\
\hline $\mathrm{Qp}$ & 1 & 55 & 34 & 69 & 15 & 10 & 44 & 11 & 38 & 39 & 38 & 30 & , & 12 & $\theta$ & 57 & 38 & 58 & 56 & 42 \\
\hline Qi & 0 & 0 & D & 1 & 0 & 0 & 0 & a & $b$ & 2 & D & D & D & 0 & a & 0 & a & b & 2 & D \\
\hline Qr & $a$ & 4 & 1 & 2 & $a$ & a & D & 0 & 8 & 2 & $D$ & D & D & 0 & $a$ & 1 & 3 & 2 & 2 & 1 \\
\hline Ks & 4 & 38 & 52 & 64 & 16 & 13 & 46 & 13 & 69 & 71 & 61 & 50 & B & 24 & 18 & 63 & 73 & 68 & 58 & 48 \\
\hline Kr & a. & 2 & 2 & 1 & a & a & D & a & 1 & 1 & D & D & D & 0 & a & a & 1 & 1 & 2 & D \\
\hline Mf & 24 & $\geqslant$ & 5 & 2 & 5 & $t$ & 8 & 1 & 2 & 4 & b & 2 & D & t & $t$ & 0 & 2 & b & 2 & D \\
\hline $\mathrm{Ch}$ & $a$ & a & 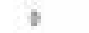 & 1 & 1 & $t$ & 0 & $\mathrm{t}$ & 1 & 4 & D & 1 & b & 0 & $t$ & 1 & 1 & b & 3 & 0 \\
\hline $\mathrm{Mc}$ & 3 & 0 & 2 & 0 & 0 & 0 & 0 & 0 & 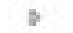 & 4 & b & 0 & b. & 0 & 0 & 1 & 0 & 0 & 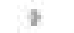 & 0 \\
\hline Ot & 4 & 4 & 14 & 6 & $?$ & 9 & 10 & 7 & 5 & 15 & $T$ & 16 & 5 & 15 & 12 & 6 & 4 & 5 & 6 & 10 \\
\hline Sc & 2 & 1 & 11 & 2 & 31 & 5 & 2 & 1 & 1 & 2 & 5 & 2 & $D$ & 1 & a & 2 & 2 & , & 7 & 15 \\
\hline $\mathrm{Sf}$ & a. & 0 & 1 & $a$ & a & a & 0 & $a$ & $b$ & 4 & D & 0 & D & 0 & a & 0 & a & b & 1 & D \\
\hline $\mathrm{Sm}$ & a & 2 & 1 & 1 & 0 & 0 & 0 & 0 & 1 & $d$ & D & 0 & D & 0 & 0 & 0 & 0 & 6 & 1 & 0 \\
\hline $\mathrm{Lm}$ & 66 & 14 & 31 & 12 & 106 & 105 & 95 & 67 & 93 & 47 & 64 & 53 & 42 & 98 & 140 & 44 & 65 & 45 & 28 & 49 \\
\hline $\mathrm{Lmb}$ & 31 & 2 & 12 & 2 & 13 & 9 & 9 & 15 & 1 & 5 & 6 & 7 & 13 & 35 & 38 & 5 & $?$ & 5 & 3 & 3 \\
\hline Lmr & 6 & 1 & 3 & 1 & 5 & 0 & 1 & 5 & 3 & 1 & 3 & 2 & 0 & 1 & 4 & 0 & 0 & 8 & 1 & 1 \\
\hline $\mathrm{L}_{\mathbf{g}}$ & 22 & $b$ & 18 & 3 & 19 & 17 & 7 & 2 & 11 & \& & 13 & 5 & 1 & 11 & 3 & 1 & 5 & 3 & t & 6 \\
\hline Le & 25 & 10 & 1 & 6 & 34 & 10 & 12 & 14 & 3 & 3 & 4 & 5 & 18 & 24 & 28 & 0 & 3 & 5 & 3 & 4 \\
\hline Lc & 41 & 5 & 23 & 3 & 12 & 11 & 13 & 22 & 10 & 6 & 6 & 5 & 105 & 41 & 25 & 3 & 22 & 22 & 12 & 18 \\
\hline $\mathrm{F} \bullet$ & 60 & $t$ & 3 & 4 & 5 & 3 & 4 & 1 & 4 & $\mathbb{1}$ & 3 & 2 & 9 & 21 & 16 & 9 & 4 & e & 1 & 2 \\
\hline Ls & 1 & 3 & 13 & 3 & 33 & 12 & 11 & 3 & 17 & I & 4 & 14 & 2 & 4 & 6 & 1 & A & $T$ & 4 & 4 \\
\hline $\mathbf{D m}$ & 80 & I & 1 & 3 & 9 & 0 & 0 & 1 & 2 & 1 & 0 & 0 & 35 & 3 & 4 & 1 & 0 & 2 & 2 & 3 \\
\hline De & 3 & 0 & 8 & 3 & 1 & 0 & 0 & 0 & 8 & 0 & D & 0 & 44 & 3 & 5 & 0 & 1 & D & 3 & 0 \\
\hline Dc & 4 & 2 & 1 & 2 & a & 0 & D & a & 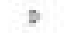 & 0 & D & 0 & 8 & 9 & 10 & 7 & 2 & 2 & 1 & 1 \\
\hline Dd & 16 & 0 & $\geqslant$ & 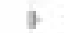 & 0 & 0 & 2 & 9 & 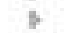 & 1 & 1 & 9 & 85 & 24 & 26 & 0 & 0 & 1 & 1 & 1 \\
\hline $\mathbf{D}_{s}$ & 1 & 0 & 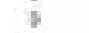 & 3 & 9 & 0 & 0 & 9 & b & 3 & D & 0 & 2 & 1 & 9 & 2 & 0 & 3 & 1 & 2 \\
\hline $\mathrm{Bi} \bullet$ & 0 & 0 & 8 & 0 & 0 & 0 & 0 & 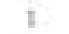 & 8 & 4 & D & 0 & D & 0 & 0 & 0 & 0 & 0 & 3 & 0 \\
\hline In & 12 & 4 & $T$ & $a$ & 3 & 176 & 21 & 256 & 12 & 5 & 4 & 1 & 1 & 3 & 44 & 4 & 3 & 3 & 1 & 3 \\
\hline $\mathrm{XQm}$ & a & 11 & 8 & 1 & 2 & 7 & 7 & $\mathrm{t}$ & 8 & 2 & 2 & 3 & D & 0 & 2 & 1 & a & $D$ & $a$ & 1 \\
\hline$X Q p$ & 0 & 4 & 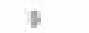 & 0 & 9 & 3 & 2 & 1 & 1 & 3 & D & 2 & D & 0 & 0 & 0 & 0 & $\theta$ & 3 & 0 \\
\hline XQi & 0 & 0 & 8 & 3 & $a$ & 0 & 0 & a & 8 & 9 & D & 0 & D & 0 & 9 & 0 & 0 & 0 & 3 & 0 \\
\hline $\mathrm{XQr}$ & 3 & 0 & 8 & a & a & 0 & 0 & a & D & 0 & D & D & D & 0 & a & 0 & a & D & $a$ & D \\
\hline XKKs & a & 10 & 8 & $a$ & 1 & 2 & 1 & 2 & 1 & 0 & 1 & 2 & D & 0 & $a$ & 0 & a & D & 1 & D \\
\hline $\mathrm{xKr}$ & $a$ & 0 & 8 & $a$ & a & 0 & D & 0 & 8 & a & D & D & D & 0 & a & 0 & a & D & 2 & D \\
\hline XIMf & 0 & $a$ & 8 & $a$ & a & a & D & a & $D$ & 0 & D & 0 & D & 0 & a & 0 & $a$ & D & 2 & 0 \\
\hline $\mathrm{XCh}$ & 3 & 0 & 8 & $a$ & a & 0 & D & a & $D$ & 0 & b & D & D & 0 & a & 0 & a & D & $a$ & D \\
\hline $2 \mathrm{MC}$ & $a$ & 0 & 8 & $a$ & a & a & D & a & 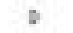 & 0 & D & D & D & 0 & a & 0 & a & D & 2 & D \\
\hline $\mathrm{XOt}$ & a & 0 & 8 & a & a & 1 & D & $t$ & $D$ & 0 & D & D & D & 0 & a & 0 & a & D & 2 & 0 \\
\hline XSc & 0 & 0 & 8 & $a$ & a & 1 & D & 0 & 8 & 0 & D & D & D & 0 & a & 0 & a & D & 9 & D \\
\hline $\mathrm{XSf}$ & 9 & 0 & 8 & $a$ & a & a & D & a & $D$ & 9 & D & D & D & 0 & a & 0 & a & D & 3 & D \\
\hline $\mathrm{XSm}$ & 3 & 0 & 8 & $a$ & a & 0 & 0 & 0 & 8 & 3 & b & 0 & D & 0 & 0 & 0 & a & D & 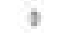 & 0 \\
\hline $\mathrm{x} L \mathrm{~m}$ & a & 0 & $b$ & 1 & 0 & 22 & 0 & 3 & b & 3 & b & 0 & b & 0 & a & 0 & 0 & b & 3 & D \\
\hline $\mathrm{xIm}$ & 3 & 0 & 1 & 1 & 0 & 9 & 0 & $a$ & 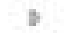 & 4 & b & 0 & b & 0 & 9 & 0 & 0 & 6 & 1 & $b$ \\
\hline $\mathrm{X} I \mathrm{mr}$ & a & a & 2 & $a$ & a & a & D & a & $D$ & 0 & D & 0 & D & 0 & a & 0 & a & 0 & 3 & 0 \\
\hline $\mathrm{XI}_{\mathrm{G}}$ & 1 & 0 & 2 & $a$ & a & 0 & D & $a$ & 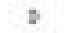 & 0 & D & D & D & 0 & a & 0 & a & D & $a$ & D \\
\hline 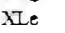 & 0 & $a$ & 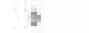 & $a$ & 1 & 2 & 0 & $a$ & 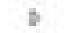 & 9 & b & 0 & D & 0 & 0 & 0 & 0 & b & 3 & 0 \\
\hline $\mathrm{XIc}$ & t & 0 & 1 & 0 & 0 & 2 & 0. & 5 & 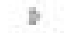 & 1 & 1 & 0 & b & 0 & 0 & 0 & 0 & $\theta$ & 2 & 0 \\
\hline $\mathrm{XF} \bullet$ & 3 & 0 & b & 1 & 0 & 0 & 0 & 0 & 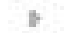 & 4 & b & 0 & 0 & 0 & 9 & 0 & 0 & 0 & 1 & 0 \\
\hline XIs & 3 & 0 & $b$ & 7 & 0 & $t$ & 0 & 9 & 3 & 3 & b & 0 & 0 & 0 & 9 & 0 & 0 & 8 & $y$ & 0 \\
\hline$x \mathrm{~m}$ & 4 & 0 & 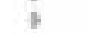 & 3 & 9 & 0 & 0 & 9 & s & 3 & D & 0 & 0 & 0 & 0 & 0 & 0 & 0 & 7 & 0 \\
\hline xDe & 1 & 0 & $b$ & 1 & a & 9 & 0 & $a$ & b & 4 & b & 0 & D & 0 & $a$ & 0 & 0 & e & 3 & D \\
\hline$x \rightarrow c$ & 3 & 0 & b & 1 & 0 & 9 & 0 & $a$ & 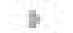 & 4 & b. & 0 & 0 & 0 & 9 & 0 & 0 & 6 & t & 0 \\
\hline $20 d$ & 3 & 0 & 1 & 1 & 0 & 0 & 0 & 9 & 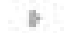 & 4 & b & 0 & 0 & 0 & 9 & 0 & 0 & D & t & 0 \\
\hline$x \mathbf{D}_{\mathrm{s}}$ & 4 & 0 & 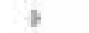 & 7 & 0 & 0 & 0 & 9 & $\Rightarrow$ & 3 & e & 0 & 0 & $\theta$ & 9 & 0 & 0 & 0 & 7 & 0 \\
\hline $\mathrm{xBi}$ & 4 & 0 & $\geqslant$ & 3 & 9 & 0 & 0 & 9 & $\Rightarrow$ & 4 & D & 0 & D & 0 & 0 & 0 & 9 & 0 & 7 & 0 \\
\hline$X] n$ & 4 & 0 & s & 3 & 9 & 1 & 0 & 9 & $B$ & 4 & D & 0 & 0 & 0 & 1 & 0 & 0 & 0 & 3 & 0 \\
\hline En & 4 & 2 & 8 & 3 & 0 & $i$ & 0 & 2 & $\Rightarrow$ & 9 & D & D & D & 0 & a & 0 & 0 & D & 3 & D \\
\hline Total & 431 & 415 & 411 & 420 & 410 & 482 & 413 & 490 & 416 & 418 & 408 & 419 & 421 & 418 & 448 & 414 & 413 & 422 & 419 & 408 \\
\hline
\end{tabular}




\begin{tabular}{|c|c|c|c|c|c|c|c|c|c|c|c|c|c|c|c|c|c|c|c|c|c|c|c|c|c|c|c|c|c|c|}
\hline & \multicolumn{2}{|c|}{ CU-13 } & \multicolumn{2}{|c|}{ CU-14 } & \multicolumn{2}{|c|}{ CU-15 } & \multicolumn{2}{|c|}{ CU-16 } & \multicolumn{2}{|c|}{ CU-17 } & \multicolumn{2}{|c|}{ CU-18 } & \multicolumn{2}{|c|}{ CU-19 } & \multicolumn{2}{|c|}{ CU-21 } & \multicolumn{2}{|l|}{ CU-22 } & \multicolumn{2}{|c|}{ CU-23 } & \multicolumn{2}{|l|}{ CU-42 } & \multicolumn{2}{|c|}{ MA-11 } & \multicolumn{2}{|c|}{$\mathrm{MA}-12$} & \multicolumn{2}{|c|}{$\mathrm{MA}-13$} & \multicolumn{2}{|c|}{ MA-14 } \\
\hline & $\%$ & $S 1 p^{\circ}$ & $\%$ & Slp & $\%$ & Slp & $\%$ & $\operatorname{sip}$ & $\%$ & Slp & $\%$ & $\operatorname{sip}$ & $\%$ & $\operatorname{sip}$ & $\%$ & Slp & $\%$ & $\operatorname{sip}$ & $\%$ & Slp & $\%$ & Slp & $\%$ & Slp & $\%$ & Slp & $\%$ & $\operatorname{sip}$ & $\%$ & Slp \\
\hline Lmwp & 12.1 & 21.5 & 12.9 & 21.2 & 14.9 & 19.5 & 13.9 & 22.3 & 11.4 & 21.4 & 10.6 & 16.8 & 11.9 & 20.1 & 28.7 & 14.3 & 38.2 & 14.2 & 10.1 & 4.9 & 0.0 & & 25.2 & 8.3 & 22.5 & 29.0 & 12.2 & 15.4 & 13.0 & 19.0 \\
\hline L gec & 0.3 & 9.6 & 0.4 & 9.6 & 0.0 & & 0.0 & & 0.8 & 9.6 & 0.0 & & 0.9 & 7.9 & 21.9 & 10.7 & 26.2 & 11.1 & 28.2 & 10.2 & 0.0 & & 0.0 & & 0.4 & 36.8 & 0.9 & 13.3 & 1.0 & 15.8 \\
\hline $\mathrm{m}$ & 12.7 & 37.5 & 13.3 & 36.7 & 17.3 & 32.3 & 17.6 & 31.9 & 13.4 & 40.5 & 14.9 & 50.4 & 14.3 & 39.2 & 4.8 & 26.2 & 0.3 & 31.4 & 0.4 & 45.0 & 0.0 & & 13.7 & 33.7 & 14.3 & 31.4 & 36.5 & 25.1 & 36.1 & 27.0 \\
\hline Dr & 27.3 & 20.5 & 22.3 & 14.3 & 19.8 & 12.6 & 30.1 & 13.5 & 24.6 & 15.0 & 43.0 & 21.3 & 12.0 & 22.1 & 23.2 & 11.1 & 26.2 & 11.1 & 28.2 & 10.3 & 100.0 & 20.5 & 24.8 & 31.8 & 23.1 & 30.9 & 34.0 & 26.8 & 33.2 & 28.3 \\
\hline AN & 23.2 & 21.3 & 26.1 & 21.3 & 21.3 & 22.7 & 13.6 & 26.3 & 25.5 & 22.1 & 10.7 & 24.3 & 31.2 & 22.7 & 9.6 & 16.6 & 3.5 & 9.4 & 15.9 & 6.6 & 0.0 & & 15.6 & 30.2 & 17.6 & 29.3 & 0.9 & 11.4 & 1.9 & 30.2 \\
\hline \multirow[t]{3}{*}{ Mar } & 24.3 & 27.4 & 24.9 & 26.8 & 26.6 & 27.1 & 24.7 & 29.4 & 24.2 & 29.3 & 20.7 & 41.1 & 29.6 & 28.4 & 11.7 & 16.9 & 5.5 & 10.5 & 17.1 & 6.3 & 0.0 & & 20.6 & 23.6 & 22.0 & 28.0 & 15.5 & 21.5 & 14.7 & 23.4 \\
\hline & \multicolumn{2}{|c|}{ MA-15 } & \multicolumn{2}{|c|}{$\mathrm{MA}-31$} & MA-3 & & $\mathrm{MA}-3$ & & MA-3 & & $\mathrm{MA}-3$ & & $\mathrm{MA} 4$ & & $\mathrm{MA}-4$ & & $\mathrm{MA} 44$ & & $\mathrm{MA}-4$ & & $\mathrm{MA}-46$ & & $\mathrm{CN}-2$ & & $\mathrm{CN}-2$ & & FU-11 & & FU-12 & \\
\hline & $\%$ & $\operatorname{slp}$ & $\%$ & Slp & $\%$ & $\mathrm{~s} 1 \mathrm{p}$ & $\%$ & $\mathrm{slp}$ & $\%$ & $\mathrm{~s} 1 \mathrm{p}$ & $\%$ & Slp & $\%$ & $\operatorname{sip}$ & $\%$ & S1p & $\%$ & Slp & $\%$ & $\mathrm{Slp}$ & $\%$ & Slp & $\%$ & $\mathrm{slp}$ & $\%$ & $\mathrm{slp}$ & $\%$ & Slp & $\%$ & Slp \\
\hline Lmwp & 12.2 & 19.0 & 0.0 & & 0.0 & & 0.0 & & 0.0 & & 0.0 & & 25.3 & 15.7 & 11.7 & 13.9 & 0.0 & & 0.0 & & 0.0 & & 17.7 & 25.6 & 17.7 & 25.6 & 0.0 & & 0.0 & \\
\hline L gec & 0.8 & 15.8 & 0.0 & & 0.0 & & 0.0 & & 0.0 & & 0.0 & & 0.0 & & 0.5 & 10.1 & 0.0 & & 0.0 & & 0.0 & & 9.9 & 27.6 & 9.9 & 27.6 & 10.9 & 28.9 & 12.0 & 17.7 \\
\hline $\mathrm{Dm}$ & 35.4 & 27.4 & 35.5 & 24.8 & 36.0 & 20.4 & 17.7 & 19.9 & 22.1 & 22.2 & 20.3 & 21.5 & 19.8 & 20.4 & 37.5 & 16.5 & 39.6 & 19.1 & 15.1 & 8.2 & 15.3 & 8.5 & 4.2 & 31.1 & 4.2 & 31.1 & 0.6 & 6.9 & 5.2 & 54.0 \\
\hline Dr & 34.1 & 29.0 & 53.2 & 24.1 & 50.8 & 19.1 & 50.1 & 17.7 & 55.3 & 18.8 & 51.5 & 19.1 & 20.8 & 21.2 & 28.2 & 17.1 & 50.6 & 17.7 & 45.7 & 8.2 & 47.0 & 8.5 & 43.0 & 31.5 & 43.0 & 31.5 & 87.5 & 32.8 & 75.4 & 24.3 \\
\hline AN & 2.3 & 31.6 & 0.0 & & 0.0 & & 13.0 & 19.7 & 0.0 & & 0.0 & & 8.0 & 32.6 & 7.0 & 36.9 & 0.0 & & 0.0 & & 0.0 & & 13.3 & 18.6 & 13.3 & 18.6 & 0.0 & & 0.0 & \\
\hline Mar & 15.1 & 24.4 & 11.2 & 23.3 & 13.1 & 14.7 & 19.1 & 20.3 & 22.5 & 20.9 & 28.1 & 16.2 & 26.0 & 18.5 & 15.0 & 19.1 & 9.7 & 12.0 & 39.1 & 8.1 & 37.6 & 8.6 & 11.8 & 21.8 & 11.8 & 21.8 & 0.9 & 6.9 & 7.3 & 54.0 \\
\hline & FU-31 & & FU 4 & & FU-4 & & FU 4 & & FU-4 & & $\mathrm{FU} 4$ & & FU-4 & & FU 4 & & TR-31 & & TR 41 & & TR -42 & & $\operatorname{TR} 4$ & & TR-44 & & TR 45 & & TE-11 & \\
\hline & $\%$ & $\operatorname{sip}$ & $\%$ & $\operatorname{slp}$ & $\%$ & $\mathrm{~s} 1 \mathrm{p}$ & $\%$ & $\operatorname{slp}$ & $\%$ & $\operatorname{sip}$ & $\%$ & $\operatorname{sip}$ & $\%$ & $\operatorname{slp}$ & $\%$ & S1p & $\%$ & $\operatorname{sip}$ & $\%$ & $\mathrm{Slp}$ & $\%$ & Slp & $\%$ & $\mathrm{slp}$ & $\%$ & Slp & $\%$ & S1p & $\%$ & Slp \\
\hline Lmwp & 14.5 & 15.3 & 20.9 & 17.2 & 21.9 & 12.3 & 13.9 & 25.1 & 7.2 & 22.9 & 10.7 & 20.9 & 6.6 & 18.6 & 6.6 & 18.6 & 3.5 & 14.4 & 74.2 & 19.8 & 51.9 & 26.5 & 9.8 & 9.9 & 59.0 & 13.2 & 50.4 & 13.6 & 40.6 & 13.3 \\
\hline I gec & 3.0 & 38.3 & 5.1 & 39.7 & 4.5 & 1.6 & 2.9 & 36.8 & 2.4 & 34.3 & 5.9 & 41.5 & 7.4 & 41.7 & 7.4 & 41.7 & 0.0 & & 14.4 & 19.4 & 10.1 & 24.8 & 49.1 & 14.8 & 18.3 & 18.2 & 25.1 & 19.3 & 21.8 & 9.4 \\
\hline $\mathrm{m}$ & 4.0 & 26.2 & 1.0 & 51.5 & 0.0 & & 12.0 & 22.1 & 26.8 & 20.3 & 8.3 & 36.3 & 5.9 & 40.6 & 5.9 & 40.6 & 1.5 & 21.1 & 1.8 & 25.6 & 0.2 & 25.3 & 0.0 & & 0.0 & & 0.0 & & 9.3 & 10.0 \\
\hline $\mathrm{Dr}$ & 33.3 & 33.3 & 54.8 & 39.9 & 68.9 & 25.0 & 53.0 & 34.3 & 63.2 & 28.3 & 48.3 & 40.7 & 43.2 & 37.9 & 43.2 & 37.9 & 74.1 & 21.5 & 0.0 & & 0.0 & & 0.0 & & 0.0 & & 0.0 & & 0.0 & \\
\hline AN & 20.0 & 28.0 & 10.0 & 49.6 & 0.9 & 15.9 & 13.1 & 40.4 & 0.0 & & 16.1 & 36.4 & 29.9 & 25.9 & 29.9 & 25.9 & 0.0 & & 0.0 & & 7.0 & 23.9 & 25.6 & 14.4 & 6.5 & 23.2 & 10.7 & 21.7 & 23.3 & $x .4$ \\
\hline Mar & 25.1 & 25.3 & 8.1 & 25.5 & 3.7 & 34.1 & 5.0 & 41.9 & 0.3 & 13.2 & 10.6 & 36.5 & 6.9 & 37.6 & 6.9 & 37.6 & 20.8 & 23.0 & 9.5 & 34.0 & 30.7 & 29.8 & 15.4 & 10.2 & 16.1 & 19.1 & 13.7 & 19.0 & 4.9 & 19.0 \\
\hline & TE-12 & & TE-12 & & TE-13 & & TE-1 & & TE-1 & & TE-16 & & TE-31 & & TE-32 & & TE-33 & & TE-34 & & TE-35 & & TE-3S & & TE-36 & & TE-37 & & TE-37 & \\
\hline & $\%$ & Slp & $\%$ & Slp & $\%$ & Slp & $\%$ & $\operatorname{sip}$ & $\%$ & Slp & $\%$ & S1p & $\%$ & Slp & $\%$ & S1p & $\%$ & sip & $\%$ & Slp & $\%$ & Slp & $\%$ & $\mathrm{~s} 1 \mathrm{p}$ & $\%$ & Slp & $\%$ & S1p & $\%$ & Slp \\
\hline Lmwp & 40.5 & 20.8 & 40.5 & 20.8 & 39.9 & 18.5 & 40.9 & 25.5 & 28.6 & 29.0 & 34.5 & 26.2 & 21.7 & 21.2 & 4.5 & 15.7 & 6.3 & 16.0 & 5.8 & 15.3 & 30.6 & 31.2 & 30.6 & 31.2 & 30.7 & 33.4 & 26.8 & 32.3 & 26.8 & 32.3 \\
\hline L gece & 13.2 & 13.9 & 13.2 & 13.9 & 15.1 & 12.0 & 13.8 & 20.1 & 11.0 & 22.7 & 12.3 & 19.5 & 6.9 & 22.5 & 3.2 & 23.6 & 4.5 & 24.0 & 4.2 & 23.0 & 11.2 & 25.4 & 11.2 & 25.4 & 9.6 & 29.1 & 9.1 & 27.2 & 9.1 & 27.2 \\
\hline $\mathrm{Dm}$ & 3.8 & 22.7 & 3.8 & 22.7 & 5.2 & 16.1 & 7.3 & 22.5 & 4.4 & 24.8 & 5.8 & 21.8 & 2.3 & 21.8 & 0.0 & & 0.0 & & 0.0 & & 5.3 & 28.9 & 5.3 & 28.9 & 4.9 & 32.2 & 4.5 & 30.6 & 4.5 & 30.6 \\
\hline Dr & 4.8 & 11.9 & 4.8 & 11.9 & 3.3 & 12.3 & 0.0 & & 0.3 & 19.0 & 0.2 & 19.0 & 21.7 & 8.5 & 83.1 & 9.9 & 76.3 & 11.7 & 78.1 & 11.7 & 0.0 & & 0.0 & & 1.0 & 32.2 & 0.6 & 30.3 & 0.6 & 30.3 \\
\hline AN & 12.0 & 15.4 & 12.0 & 15.4 & 15.4 & 12.1 & 21.0 & 18.4 & 43.3 & 20.6 & 32.6 & 19.2 & 34.2 & 24.1 & 3.4 & 23.6 & 4.9 & 24.0 & 4.5 & 23.0 & 36.4 & 24.6 & 36.4 & 24.6 & 31.8 & 28.5 & 38.1 & 24.3 & 38.1 & 24.3 \\
\hline Mar & 25.6 & 30.5 & 25.6 & 30.5 & 21.0 & 27.4 & 16.9 & 29.3 & 12.3 & 28.8 & 14.5 & 28.9 & 13.1 & 20.9 & 5.7 & 23.6 & 7.9 & 24.0 & 7.3 & 23.0 & 16.4 & 29.1 & 16.4 & 29.1 & 21.9 & 30.9 & 20.8 & 26.0 & 20.8 & 26.0 \\
\hline
\end{tabular}




\section{References}

Alvaro, M., Capote, R., Vegas, R., 1979. Un modelo de evolución geotectónica para la Cadena Celtibérica. Acta Geol. Hisp. 14, $172-177$

Arribas, M.E., Tortosa, A., 1998. Coeval carbonate grains in modem fluvial sands (Iberian Range, Spain): the activity of a continental carbonate factory. In: Cañaveras, J.C., García del Cura, M.A., Soria, J. (Eds.), Abstracts of the 15th Intemational Sedimentological Conference, Alicante, Spain, p. 154.

Arribas, J., Gómez-Gras, D., Rosell, J., Tortosa, A., 1990. Estudio comparat ivo en re las areniscas Paleozoicas y Triásicas de la isla de Menorca: evidencias de procesos de reciclado. Rev. Soc. Geol. Esp. 3, 105-116

Arribas, J., Critelli, S., Le Pera, E., Tortosa, A., 2000. Composition of modem stream sand derived from a mixture of sedimentary and metamorphic source rocks (Henares River Cen $\mathbf{m a l}$ Spain) Sediment. Geol. 133, 27-48.

Basu, A., 1985. Influence of climate and relief on compositions of sands released at source areas. In: Zuffa, G.G. (Ed.), Provenance of Arenites. Reidel, Dordrecht, pp. 1-18.

Basu, A., Young, S.W., Sutmer, L.J., James, W.C., Mack, G.H., 1975. Re-evaluation of the use of undulatory extinction and polycrystallinity in detrital quartz for provenance interpretation. J. Sediment. Petrol. 45, 873-882

Bathurst, R.G.C., 1975. Carbonate Sediments and Their Diagenesis. Elsevier, Amsterdam, $658 \mathrm{pp}$.

Blatt, H., Jones, R.L., 1975. Proportions of exposed igneous, metamorphic, and sedimentary rocks. Geol. Soc. Amer. Bull. 86, 1085-1088.

Blatt, H., Middleton, G.V., Murray, R.C., 1980. Origin of Sedimentary Rocks. Prentice-Hall, New Jersey, 634 pp.

Cavazza, W., Zuffa, G.G., Camporesi, C., Ferretti, C., 1993. Sedimentary recycling in a temperate climate drainage basin (Senio River, north-cen Italy): composition of source rock, soil profiles, and fluvial deposits. In: Jolınsson, M.J., Basu, A. (Eds.), Processes Controlling the Composition of Clastic Sediments. Geol. Soc. Am. Special Paper, vol. 284, pp. 247-261.

Chave, K.E., Schmalz, R.F., 1966. Carbonate-seawater reactions. Geochim. Cosmochim. Acta 30, 1037-1048.

Chayes, F., 1952. Notes on the staining of posh feldspar with sodium cobaltinitrite in thin section. Am. Mineral. 37, 337-340

Dickinson, W.R., 1970. Interpreting detrital modes of graywacke and arkose. J. Sediment. Petrol. 40, 695-707.

Dickinson, W.R., 1985. Interpreting provenance relations from detrital modes of sandstones. In: Zuffa, G.G. (Ed.), Provenance of Arenites. Reidel, Dordrecht, pp. 333-362.

Dickinson, W.R., Suczek, C.A., 1979. Plate tectonics and sandstone composition. AAPG Bull. 63, 2164-2182.

Dickinson, W.R., Beard, L.S., Brakenridge, G.R., Erjavec, J.L., Ferguson, R.C., Inman, K.F., Knepp, R.A., Lindberg, F.A., Ryberg, P.T., 1983. Provenance of north American phanerozoic sandstones in relation to tectonic setting. Geol. Soc. Amer. Bull. 94, 222-235

Evamy, B.D., 1963. The application of chemical staining teclunique to a study of delomitization. Sedimentology 2, 164-170

Femández Calvo, C., 1981. Sedimentología y diagénesis del Cre- tácico Superior de La Mancha (Cuenca). PhD Thesis, Univ. Complutense, Madrid, $299 \mathrm{pp}$

Folk, R.L., 1974. Perology of Sedimentary Rocks. Hemphill Publishing, Austin, TX, $182 \mathrm{pp}$.

Freytet, P., Verrecchia, E.P., 1998. Freshwater organisms that build stromatolites: a synopsis of biocrys allization by prokaryotic and eukaryotic algae. Sedimentology 45, 535-563.

Garrels, R.M., 1986. Sediment cycling and diagenesis. U.S. Geol. Surv. Bull. 1578, 1-11.

Gazzi, P., 1966. Le arenarie del flysch sopracretaceo dell'Appennino modenese; correlazioni con il Flysch di Monghidoro. Mineral. Petrogr. Acta 12, 69-97

Grantham, J.H., Velbel, M.A., 1988. The influence of climate and topography on rock-fragment abundance in modern fluvial sands of the southem Blue Ridge Mountains, North Carolina. J. Sediment. Petrol. 58, 219-227.

Ibbeken, H., Schleyer, R., 1991. Source and sediment. A Case Study of Provenance and Mass Balance at an Active Plate Margin (Calabria, Southem Italy). Springer-Verlag, Berlin, $286 \mathrm{pp}$.

I.G.N., 1991a. Atlas Nacional de España; II.9, Climatología, Instituto Geograf co Nacional, Ministerio de Obras Públicas y Transportes (MOPT), Madrid, $24 \mathrm{pp}$.

I.G.N., 1991 b. Atlas Nacional de España; II.7, Edafología, Instituto Geografico Nacional, Ministerio de Obras Públicas y Transportes (MOPT), Madrid, $14 \mathrm{pp}$.

Ingersoll, R.V., Bullard, T.F., Ford, R.L., Grimm, J.P., Pickle, J.D., Sares, S.W., 1984. The effect of grain size on detrital modes: a test of the Gazzi-Dickinson point-counting method. J. Sediment. Petrol. 54, $103-116$.

Ingersoll, R.V., Kretchmer, A.G., Valles, P.K., 1993. The effect of sampling scale on actualistic sandstone perofacies. Sedimentology 4., 937-953.

I.T.G.E., 1983a. Mapa Geológico de España. Escala 1/50.000. Hoja no. 589. Terriente. Memoria explicativa, $80 \mathrm{pp}$

I.T.G.E., 1983b. Mapa Geológico de España. Escala 1/50.000. Hoja no. 565. Tragacete. Memoria explicativa, $89 \mathrm{pp}$.

I.T.G.E., 1986. Mapa Geológico de España. Escala 1/50.000. Hoja no. 611. Cañete. Memoria explicativa, $64 \mathrm{pp}$.

I.T.G.E., 1989a. Mapa Geológico de España. Escala 1/50.000. Hoja no. 610. Cuenca. Memoria explicativa, $56 \mathrm{pp}$

I.T.G.E., 1989b. Mapa Geológico de España. Escala 1/50.000. Hoja no. 564. Fuertescusa. Memoria explicativa, $54 \mathrm{pp}$.

I.T.G.E., 1989c. Mapa Geológico de España. Escala 1/50.000. Hoja no. 587. Las Majadas. Memoria explicativa, $6 \mathrm{pp}$.

Jolunsson, M.J., 1993. The system controlling the composition of clastic sediments. In: Jolınsson, M.J., Basu, A. (Eds.), Processes Con rolling the Composition of Clastic Sediments. Geol. Soc. Am. Special Paper, vol. 284, pp. 1-19.

Köppen, W., 1901. Versuch einer Klassifikation der klimate vorzugsweise nach ihren Beziehungen zur Pflanzenwelt. Geogr. Z. 6 (593 pp.).

Le Pera, E., Arribas, J., Critelli, S., Tortosa, A., 2001. The effects of source rocks and chemical weathering on the perogenesis of siliciclastic sand from the Neto river (Calabria, Italy): implications for provenance studies. Sedimentology 48, 357-378.

Mack, G.H., 1981. Composition of modern stream sand in a humid climate derived from a low-grade metamorphic and sedimentary 
foreland fold-thrust belt of north Georgia. J. Sediment. Perol. $51,1247-1258$

Montesinos, S., Arribas, J., 1998. Source area versus detrital products: a geographical information system approach. In: Cañaveras, J.C., García del Cura, M.A., Soria, J. (Eds.), Abstracts of the 15th International Sedimentological Conference, Alicante, Spain, pp. 558-559.

Moulton, K.L., Bemer, R.A., 1998. Quantification of the effect of plants on weathering: studies in Iceland. Geology 26, 895-898.

Odom, I.E., Doe, T.W., Dott, R.H., 1976. Nature of feldspar-grain size relations in some quartz-rich sandstones. J. Sediment. Petrol. $46,862-870$.

Palomares, M., Arribas, J., 1993. Modern stream sands from compound crystalline sources: composition and sand generation index. In: Jolunsson, M.J., Basu, A. (Eds.), Processes Controlling the Composition of Clastic Sediments. Geol. Soc. Am. Special Paper, vol. 284, pp. 313-322.

Pedley, H.M., 1990. Classification and environmental models of cool freshwater tufas. Sediment. Geol. 68, 143-154.

Potter, P.E., 1978. Petrology and chemistry of modem big river sands. J. Geol. 86, 423-449.
Potter, P.E., 1994. Modem sands of south America: composition, provenance and global significance. Geol. Rundsch. 83, $212-232$.

Reeder, R.J., 1983. Crystal chemis of the rhombohedral carbonates. Min. Soc. Am. Rev. Mineral. 11, 1-48.

Valloni, R., 1985. Reading provenance from modem marine sands. In: Zuffa, G.G. (Ed.), Provenance of Arenites. Reidel, Dordrecht, pp. 309-332.

Vilas, L., Mas, R., García, A., Arias, C., Alonso, A., Meléndez, N., Rincón, R., 1982. Ibérica suroccidental. El Cretácico de España. Univ. Complutense Madrid, Madrid, pp. 457-514.

Wilson, L., 1969. Les rélations entre les processus géomorphologiques et le climat moderne comme méthode de paléoclimatologie. Rev. Géogr. Phys. Géol. Dyn. 11, 303-314.

Zuffa, G.G., 1980. Hybrid arenites: their composition and classifcation. J. Sediment. Petrol. 50, 21-29.

Zuffa, G.G., 1987. Unravelling hinterland and offshore paleogeography from deep-water arenites. Deep-Marine Clastic Sedimentology. In: Leggett, J.K., Zuffa, G.G. (Eds.), Concepts and Case Studies. Graham and Trotman, London, pp. 39-61. 